\title{
HEAT TRANSFER THROUGH BUILDING WALLS
}

\author{
By M. S. Van Dusen and J. L. Finck
}

\begin{abstract}
A method for measuring the heat transfer through large flat slabs, such as wall sections, is described in detail. The method requires no actual measurement of heat flow over large areas and no accounting for inevitable losses in undesired directions, except where lateral losses may occur by radiation, but consists in comparing the thermal resistance of an unknown panel with a standard, the resistance of which can be accurately determined by the hot-plate method, by which the measurement of heat How is made under much more favorable conditions.

Results on 17 walls are given. The accuracy of the measurements is of the order of 5 per cent in the apparatus described. Greater accuracy than this can only be attained by better control of conditions, which becomes increasingly difficult as the temperature variation limits are narrowed. Such refinements would seem to be superfluous, however, in view of the degree of reproducibility of such structures as building walls.

In addition to the above, results are also given for five small panels, these observations being made with a hot plate 24 inches square. These smaller panels consisted of certain individual components of frame wall construction.

An analysis of the data permitted the calculation of the conductances and resistances of the various components entering into the construction of ordinary types of walls. These values are presented in tabular form, and their use permits the calculation of the resistance (or conductance) of any combination of the various components for which data are given. The resistances of a number of wall combinations were calculated and compared with the data of other experimenters. The agreement is, in general, fairly satisfactory.
\end{abstract}

\section{CONTENTS}

I. Introduction

II. Principles of heat transfer through walls

1. Heat flow under steady conditions . .

2. Surface resistance

3. Wall resistance

4. Heat transfer by air infiltration

5. Heat flow under variable conditions

III. Experimental arrangements and methods of test....

1. Apparatus .

2. Conductimeter

3. Walls

4. Operation

IV. Results and discussion

V. Tests on small panels by hot-plate meihod.

VI. Calculation of the conductance, resistance, and transmittance of walls and component parts

VII. Review and comparison of data of previous experimenters.

VIII. Summary and general conclusions

IX. Acknowledgments . 


\section{INTRODUCTION}

The heat transfer through building walls has been the subject of considerable investigation in the past, but the wide discrepancies in existing data seem to warrant further investigation, at least to the point where the heat transfer through the more common types of exterior walls can be estimated with a fair degree of approximation. This has been possible in the case of the walls of cold-storage buildings where a considerable thickness of insulating material is applied, since the thermal conductivity of the latter class of materials is either known or easily measured, and the structural portions of the wall contribute relatively so little resistance to heat flow that their thermal properties need only be very roughly known. Ordinary building walls, however, present a different problem, and it is not feasible, in many cases, to calculate the heat transfer from a mere knowledge of the thermal conductivities of the various materials composing the wall, although such a procedure is not theoretically impossible. In fact it is very desirable to proceed in this direction as far as possible, even with our present incomplete knowledge of data of heat transfer, since it results in a large reduction in the number of separate experiments required to obtain working data on a large number of combinations.

Building walls can be reproduced with only a fair degree of approximation; consequently it is of no particular value to attempt to measure the thermal properties of a single specimen with much greater accuracy than this type of construction is ordinarily reproduced. The degree of reproducibility, however, is difficult to estimate, and varies greatly with the type of wall, character of workmanship, etc.; consequently it is practically necessary to choose some reasonable limits of error and attempt to keep within them.

The present paper gives the results of an investigation pertaining essentially to the development of a practical method for measuring the heat transfer through building walls under laboratory conditions which can be reproduced and controlled. Measurements were made on some of the more common types of walls used in the construction of buildings.

\section{PRINCIPLES OF HEAT TRANSFER THROUGH WALLS}

\section{HEAT FLOW UNDER STEADY CONDITIONS}

The steady flow of heat through a wall by reason of a constant temperature difference between the surroundings on the two sides depends upon four partially independent processes, (1) the transfer of heat to the wall from the surroundings on the hot side, (2) the transfer through the wall, (3) the transfer of heat to the surroundings on the cold side, and (4) the diffusion or flow of air through the wall in either direction. Neglecting for the present the eflect of possible air leakage, let us first discuss, in general, the other three processes or factors mentioned above.

The total resistance to heat flow through the wall is the sum of the resistance of the wall itself and the two resistances between the surfaces of the wall and their respectivesurroundings. The thermal resistance per unit area may be defined quantitatively as the number of degrees temperature difference required between the boundaries of the system 
(surfaces or surroundings, as the case may be) to produce unit rate of heat flow through unit area, the direction of flow being normal to the area. The reciprocal of the resistance per unit area of a system of solid materials in layers is the conductance per unit area, defined as the rate of heat flow through unit area produced by a temperature difference of $1^{\circ}$ between the boundaries of the system. It will also be convenient to speak of two other quantities, viz, thermal conductivity and transmittance per unit area. Thermal conductivity is a property of a homogeneous material, and is defined as the rate of heat flow through unit area when the temperature difference perpendicular to the area is $1^{\circ}$ per unit thickness. Transmittance is a term applied to the over-all heat transfer from air to air, and is therefore the reciprocal of the total resistance from air to air.

The values of the quantities defined above are not strictly constants but vary with the mean temperature and the temperature difference, but the variations are small and for the present these quantities will be treated as constants for the sake of simplicity and clearness. If necessary any variations in them can be taken into account in the solution of actual problems.

\section{SURFACE RESISTANCE}

The resistance to heat flow between the surface of a wall and its surroundings is ordinarily called surface resistance, although it is only partially dependent upon phenomena taking place at the surface of the wall. The transfer of heat takes place by all the modes of heat transfer, viz, conduction, convection, and radiation, and the relative contribution of each depends upon the conditions. Heat is transferred from the air to the wall, or vice versa, by convective air currents set up by temperature differences between wall and air, by wind or forced ventilation. At points very near the wall the velocity of the air is reduced; the motion becomes approximately streamline, and heat is transferred from these regions to the solid surface of the wall mainly by pure conduction through layers of air moving parallel to the wall, and therefore not transferring heat to it by turbulent motion. Some convection, of course, occurs even fairly near the surface. For a constant mean velocity of moving air, the heat transferred between air and wall will be very nearly proportional to the temperature difference, or, in other words, the surface resistance due to air only will be a constant, and independent of the temperature difference. The resistance will, however, decrease greatly with increased air velocity. In the case of natural convection, the air velocity increases with increasing temperature difference; consequently, the surface resistance will decrease with increasing temperature difference, and may be regarded as depending only upon the temperature difference and the mean temperature. The variation of the resistance with the mean temperature is too small to be of much importance in this connection, but the variation with air velocity is important, since in a moderate breeze the resistance is reduced to a very small value relative to the total resistance of the wall.

In addition to the heat transferred by convection and conduction in the air, an entirely independent transfer takes place by radiation between the surface of the wall and its surroundings. The magnitude of such transfer depends on the absolute temperature, the temperature difference, and the character of the surfaces of the wall and surround- 
ings. If the wall and its surroundings had reflecting surfaces of clean, bright metal, the interchange of heat by radiation would be very small at ordinary temperatures. In all practical cases, however, the surfaces are nonmetallic, and the transfer of heat by radiation is usually somewhat greater than the convective transfer, even at ordinary teinperatures. Furthermore, the radiating and absorbing properties for the kind of radiation emitted at ordinary temperatures are practically the same for any materials likely to be found either on the wall surface or on the surroundings. The heat interchange by radiation may, therefore, be considered as dependent only on the temperatures in almost all practical cases. For moderate temperature differences, the heat transfer by radiation is proportional to the product of the temperature difference and the cube of the absolute temperature. The variation with the absolute temperature amounts to about 1 per cent per ${ }^{\circ} \mathrm{C}$. at ordinary temperatures, but this variation, although considerable, is not of much importance in dealing with the total thermal resistance of a wall.

The surface resistance is the numerical measure of the complicated combination of all the effects of conduction, convection, and radiation. It is ordinarily defined as the temperature difference between the solid surfaces of the wall and the surrounding air required to produce unit rate of heat flow per unit area of wall surface. The air temperature is supposed to be measured at sufficient distance from the wall surface such that the effect of the wall is inappreciable. Strictly speaking, such a definition can only apply if all the surroundings are at the same temperature as the air, since the transfer of heat by radiation is independent of the air temperature, except in so far as the air influences the temperature of the surroundings.

\section{WALL RESISTANCE}

The thermal resistance of the wall itself is separate and distinct from the surface resistances. It is a property of the wall and is not influenced by the surroundings except in certain cases of air leakage which will be noted later. Heat transfer through solid walls takes place only by conduction in the direction of temperature gradients. Such transfer is proportional to the temperature difference between the two surfaces of the wall and further depends on the materials composing the wall. The thermal conductivities of building materials in general, increase slightly with increasing temperature; consequently the resistance of a wall will decrease somewhat with increasing mean temperature of the wall.

Heat transfer through walls containing voids, such as hollow tile, frame, or the hollow types of brick walls, takes place by convection and radiation as well as conduction. The resultant process is very complicated in any ordinary type of hollow-wall construction, and it is at present difficult to separate the three effects and ascertain which one plays the most important rôle in any particular type of construction. Our knowledge of the heat transfer in inclosed air spaces is limited at present, but it may be said, in general, that such transfer will increase with the temperature by significant amounts due primarily to the large variation in radiation. Walls of this nature are subject to much greater variation in construction than solid walls, since more or less mortar is forced into air spaces, depending upon chance and the individual workman. 


\section{HEAT TRANSFER BY AIR INFILTRATION}

Aside from conduction, convection, and radiation, an entirely independent transfer of heat may take place by infiltration of cold air through the wall on the windward side of a building, with the consequent efflux of warmer air on the lee side of a building. In an extreme case, air infiltration may be so large as to cause material change in the temperature gradient in the wall, and, therefore, influence the outward heat flow by conduction. No discussion of such an extreme case, however, will be made here.

The magnitude of the effects of air infiltration through walls has been investigated in recent years by Houghten and Ingels, ${ }^{1}$ and also by Larson, Braatz, and Nelson, ${ }^{2}$ and the general conclusion seems to be that infiltration through plastered and finished walls plays, on the average at least, a very minor rôle in the heat loss from buildings. It must be remembered, however, that all the measurements referred to are concerned directly with air flow through the wall by reason of pressure differences; no direct measurements of heat transfer under conditions of wind pressure having been made. It is evident that an impermeable layer at any place in the wall will entirely eliminate air infiltration to the interior, but not necessarily annul the effects of partial air penetration on the total heat loss through the wall. If the relatively impermeable (to air) layer is on the inside of the wall (as it usually is), the possibility of penetration of cold air part way into the wall and out again must be recognized. If the outward path for air flow is directly against the wind pressure causing the penetration, it is to be expected that a sort of equilibrium will be maintained, with little or no heat transfer by air movement. On the other hand, if there is an open path for air flow into an air space on the windward side and out at some point at lower pressure, for example the attic or the lee side, the resulting effect will be a heat loss from the building. The magnitude of such effects is on the average wholly problematical, but probably not very great. In certain individual buildings, however, the effect is undoubtedly large. Obviously, walls containing air spaces should be protected as well as possible on the outside against air infiltration.

\section{HEAT FLOW UNDER VARIABLE CONDITIONS}

When the temperature of any or all points in the system considered varies with time, certain other factors enter into the problem of heat flow through a wall. It is evident that the variable condition is the only one which actually occurs in practice, not so much on account of the small rapid variations in temperature, but rather to the large variations from day to night. As the air temperature and external wall surface temperature fall rapidly during the night, heat flows outward from the wall at a greater rate than it flows into the wall from the inside. The flow of heat into the outside air is maintained at the expense of heat stored in the wall, and it is only when this store is exhausted that a steady state is again established. In a thick wall with large heat capacity it may require several days for the steady state to become approximately established; consequently, by morning

1 J. Am. Soc. Heating and Ventilating Eng., 33, pp. 249-258; 1927.

2 J. Am. Soc. Heating and Ventilating Eng., 35, pp. 125-132; 1929.

$36798^{\circ}-31-10$ 
that portion of the wall near the inside of the building is still losing heat at practically the same rate as it was the night before. The morning rise in temperature on the outside then tends to counteract the cooling of the previous night, the outer portions of the wall store up the heat lost the night before, and the inside portions of the wall, and consequently the net outward heat flow from the interior, remain practically unaffected from day to day, provided the same temperature conditions are repeated. Slower variations in temperature, however, such as cold or warm waves extending over a period of several days, have time to penetrate to the inside surface of the wall, and their effects are consequently felt.

The net outward heat flow, however, in the case of uniform periodic variation in outside temperature is the same as it would be if the outside were kept at some uniform mean temperature between the maximum and minimum outside temperatures.

Suppose we consider two walls, each having the same thermal resistance (measured in a steady state), but different heat capacities, such as a solid wall and a wall made up of air spaces and paper. Under the same steady conditions the heat transfer through each will be the same. Under the same varying temperature on the outside, the net heat flow integrated over a complete period will still be the same, but a different procedure must be followed in each case to maintain the inside at constant temperature. In the case of a thick solid wall, a constant heat supply will accomplish this object, assuming that the period of the fluctuation of the outside temperature is equal to 24 hours. With the air-space wall, however, more heat must be furnished to the inside during the night than during the day, since such a wall as we have assumed has very little heat capacity.

If the object is to maintain a fairly uniform temperature indoors at all times, the solid wall has a certain obvious advantage over the wall with small heat capacity, although the consumption of fuel in each case is the same if the same temperature conditions are maintained.

We have here considered two extreme cases for the sake of example. In actual practice, the differences between two walls having the same resistance are much less and probably not of very great importance in heating during cold weather. In summer, however, on sides exposed to the sun, walls having large heat capacity tend to keep the building cooler during the hot part of the day.

\section{EXPERIMENTAL ARRANGEMENTS AND METHODS OF TEST}

The main object of the present series of measurements has been to compare the thermal resistance of various types of walls under reproducible and constant conditions. These conditions have been arranged in such a way that no appreciable effects due to air leakage or moisture would seem possible. A comparison of this kind will apply equally well to a condition of variable temperature such as actually occurs in practice, but evidently will not be valid if air leakage enters as a significant factor in actual use. It seems more feasible, however, to determine air leakage separately, in terms of mass of air rather than in quantity of heat. 
The surface resistances on the two sides are not of particular importance in the laboratory comparison of the walls themselves, since, as noted previously, they are not dependent upon the walls, but rather upon conditions external to the walls. Any incidental measurements of the surface resistances, however, will be of value, although difficult to apply under service conditions.

In the present series of experiments, the method is to maintain as nearly as practicable a constant temperature difference between circulating air on the two sides of a system composed of a specimen wall panel in contact with another panel of known thermal resistance. The two panels may be considered in series, and therefore the same heat flows through both. Let

$H=$ heat flow in B. t. u. per hour, per square feet area.

$t_{1}=$ temperature in ${ }^{\circ} \mathrm{F}$. of the warm surface of the panel to be tested.

$t_{2}=$ temperature in ${ }^{\circ} \mathrm{F}$. of the cold surface of the panel to be tested. $t_{3}=$ temperature in ${ }^{\circ} \mathrm{F}$. of the warm surface of the known panel. $i_{4}=$ temperature in ${ }^{\circ} \mathrm{F}$. of the cold surface of the known panel.

$C=$ conductance per unit area for the panel to be tested. $C_{0}=$ conductance per unit area for the known panel. Then

and

$$
H=C\left(t_{1}-t_{2}\right)=C_{0}\left(t_{3}-t_{4}\right)
$$

$$
C=C_{0} \frac{t_{3}-t_{4}}{t_{1}-t_{2}}
$$

As will be described below, the temperature difference between the surfaces of the known panel are measured by a multiple-junction thermocouple. This panel is calibrated in a hot-plate apparatus. If

$E=\mathrm{e} . \mathrm{m}$. f. in millivolts of the multiple-junction thermocouple when the temperature difference is $t_{3}-t_{4}$.

$K=$ heat flow through the known panel in B. t. u. per hour, for an then e. m. f. of 1 millivolt.

and

$$
C_{o}\left(t_{3}-t_{4}\right)=K E
$$

$$
C=K \frac{E}{t_{1}-t_{2}}
$$

The resistance per unit area, $R$, is given by the equation

$$
\mathrm{R}=\frac{1}{C}=\frac{t_{1}-t_{2}}{K E}
$$

To calculate surface resistance, let $t_{a}=$ temperature in ${ }^{\circ} \mathrm{F}$ of the air several inches from the surface.

$t_{s}=$ temperature in ${ }^{\circ} \mathrm{F}$ of the surface.

$r=$ surface resistance per unit area.

If $t_{a}$ is greater than $t_{s}$, we have

$$
r=\frac{t_{a}-t_{8}}{K E}
$$

and if $t_{s}$ is greater than $t_{a}$

$$
r=\frac{t_{s}-t_{a}}{K E}
$$


This method of comparison was chosen, rather than a direct measurement of heat input, because of the great difficulty in accounting for all the heat generated on the warm side of the system. The comparison panel, on the other hand, is comparatively thin and easy to calibrate in another apparatus of known reliability.

\section{APPARATUS}

A diagrammatic sketch of the cross section of the apparatus used is shown in Figure 1. It consists of two insulated chambers each

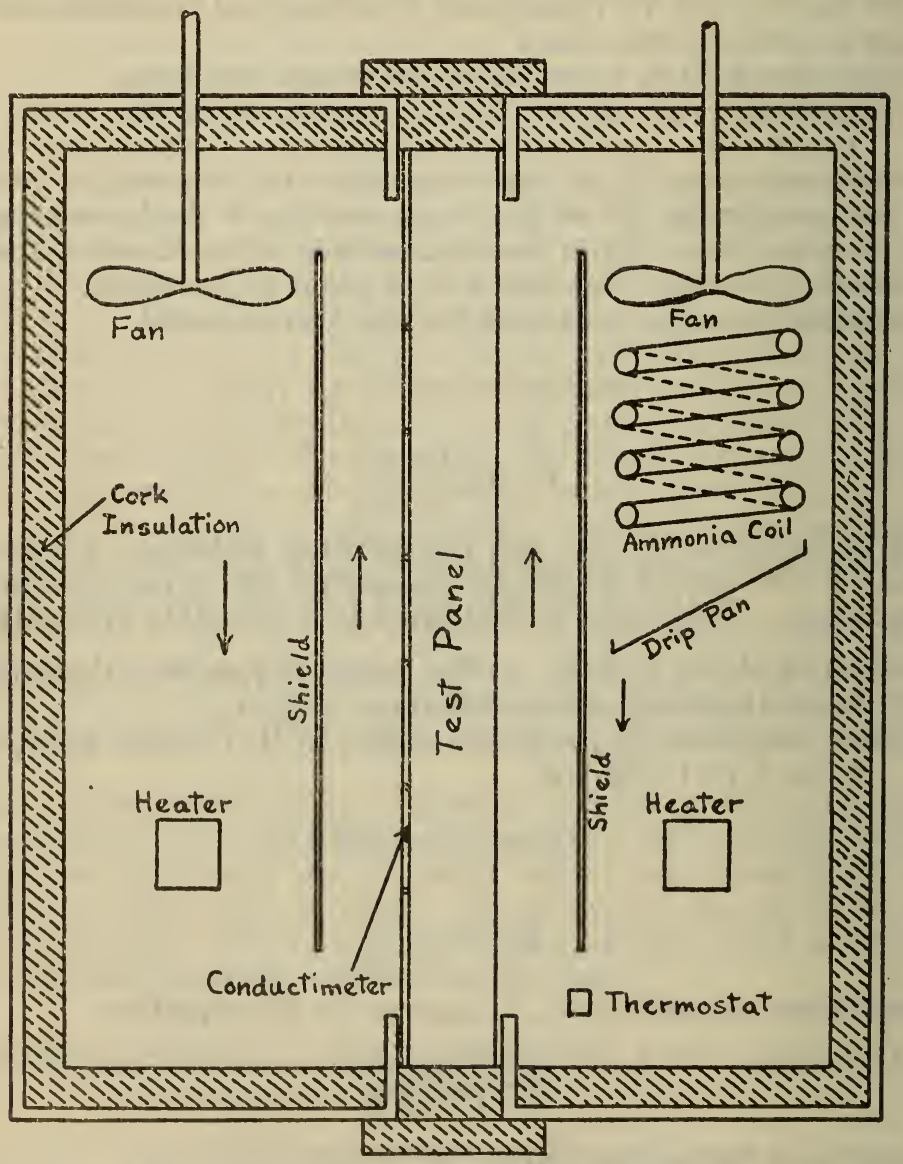

Figure 1.-Diagrammatic sketch of apparatus

open on one side, serving as the means for maintaining a temperature difference between the two sides of a wall panel placed between them. The wall panel forms a common wall on the otherwise open side of each chamber. By means of steel rods the two chambers are clamped against the panel with considerable pressure, and effectively sealed by felt gaskets. The right-hand chamber is kept at the lower temperature and is equipped with an ammonia expansion coil, an electric heating coil, a thermostat, and a fan for air circulation and heat 
B. S. Journal of Research, RP291

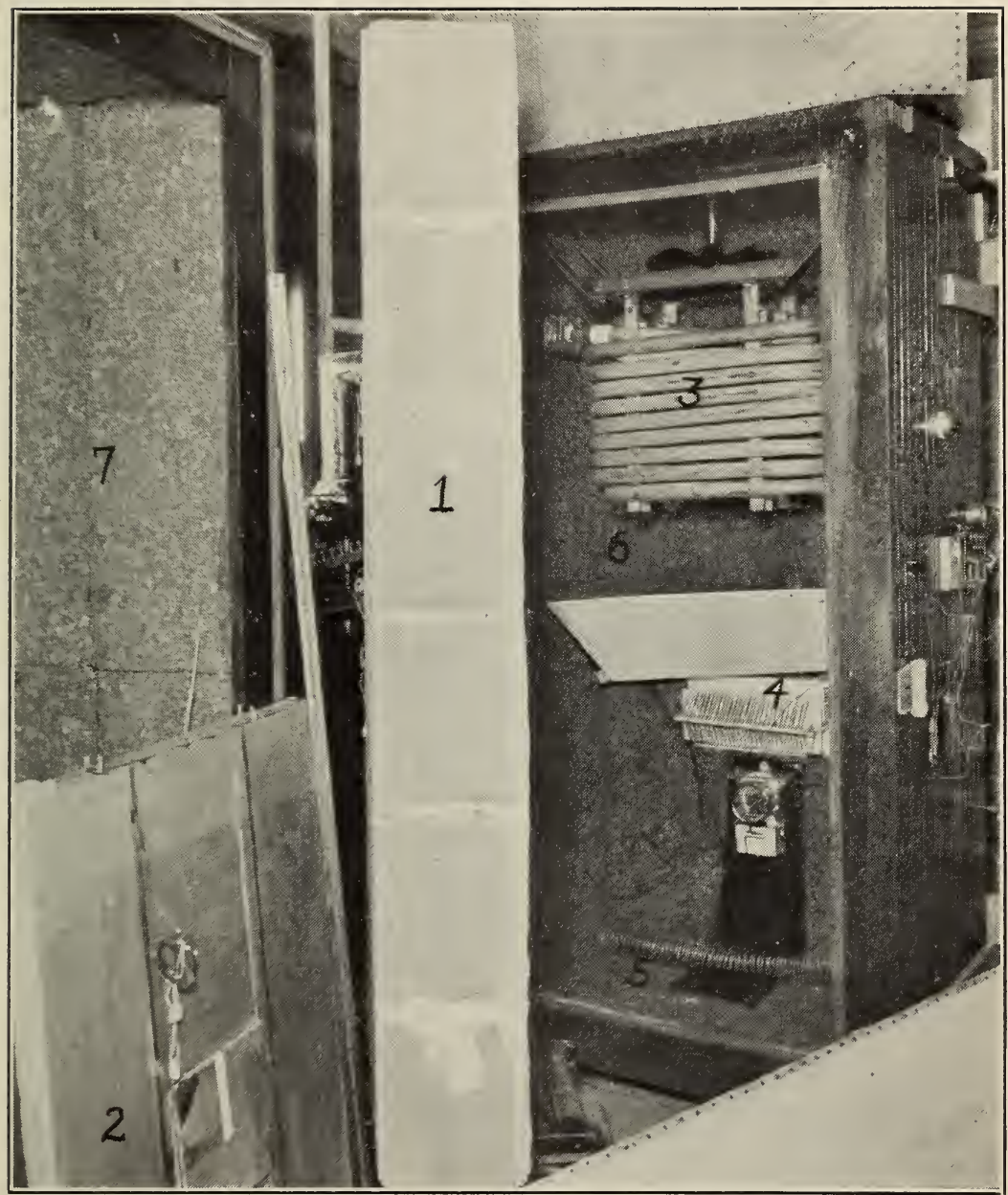

Figure 2.-Apparatus disassembled

1 , Test wall; 2 , conductimeter; 3 , cooling coil; 4 , heater; 5 , thermostat; 6 , cold chamber; 7 , warm chamber. 
B. S. Journal of Research. RP291

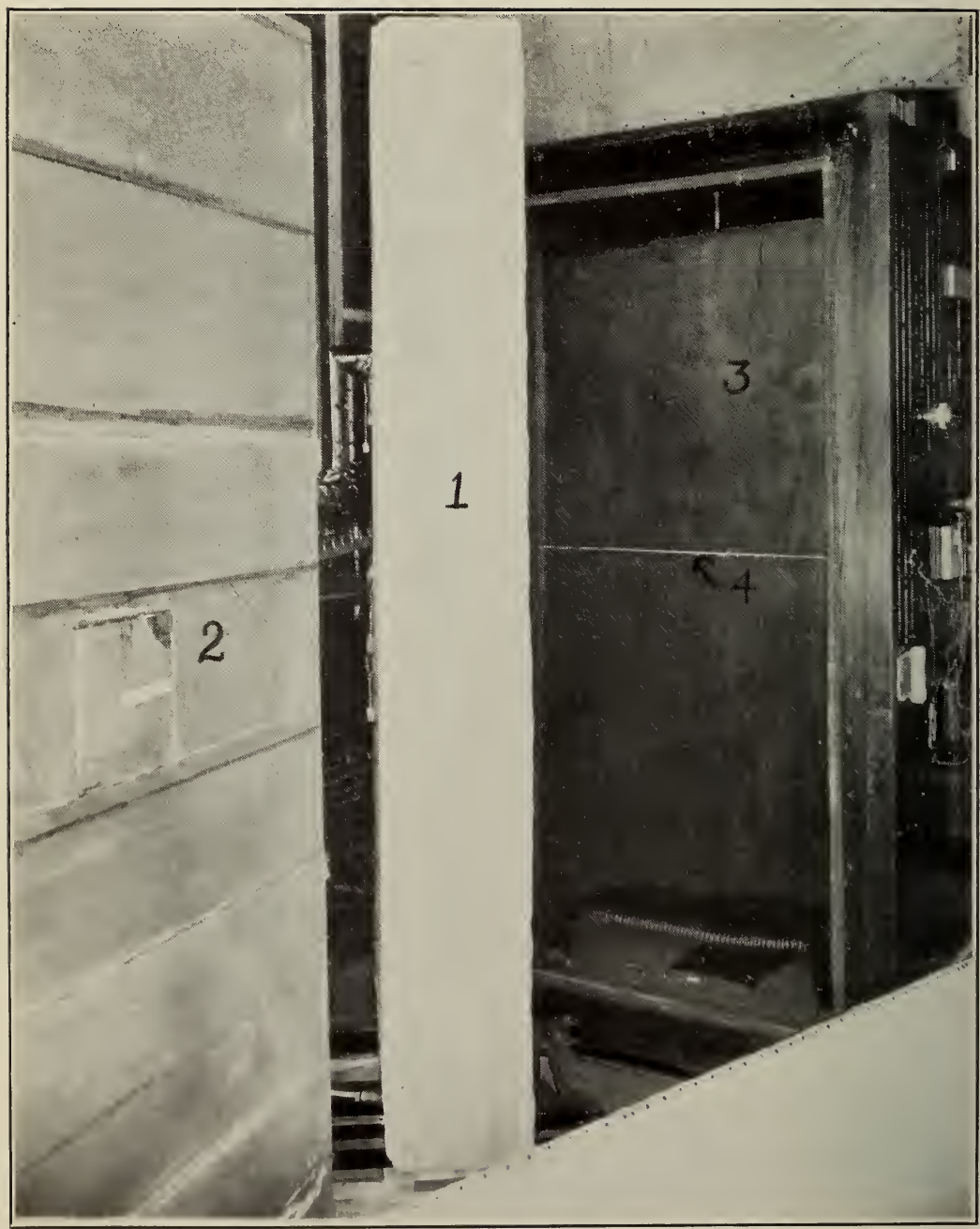

FIGULE 3.-A pparatus partly assembled

1, Test wall; 2 , conductimeter; 3 , shield in cold chamber; 4 , thermocouple which measures the cold in temperature. 
B. S. Journal of Research, RP291

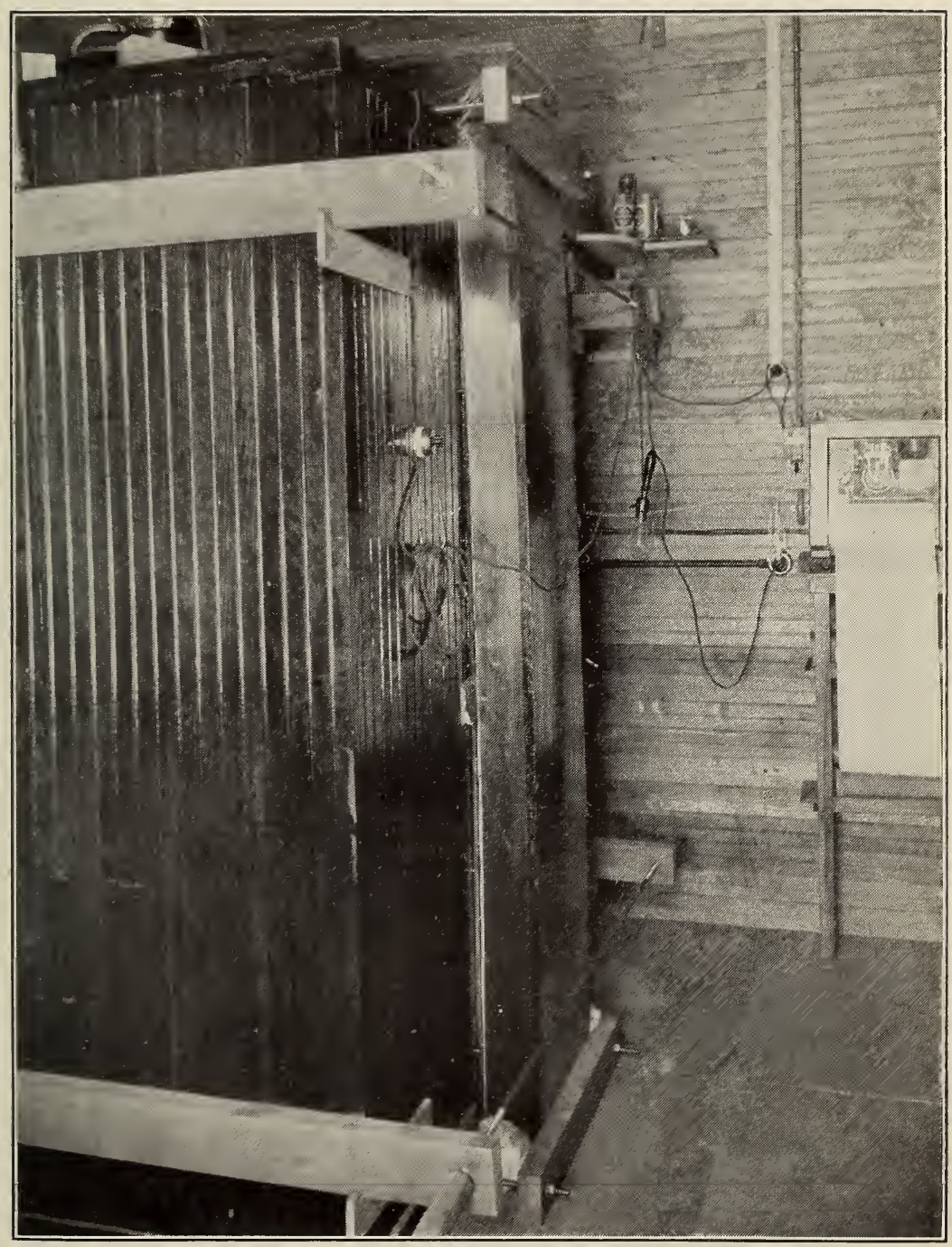

FIGURE 4.-Apparatus completely assembled 
distribution. These accessories are labeled in the sketch and are also shown in Figures 2,3 , and 4 (photographs of the apparatus in different stages of assembly). The chamber is refrigerated by means of a three-fourths-ton automatic refrigerating machine, located outside the test room. The machine is equipped with a bimetallic thermostat (shown in fig. 2) for automatically starting and stopping, but this form of control was not used, since it did not give close enough regulation. The actual method of operation was to keep the machine running all the time, the ammonia back pressure in the expansion coil being maintained constant by an automatic throttle valve. The supply of refrigeration was, therefore, approximately constant and the small fluctuations in it were balanced by heat supplied electrically and controlled by another thermostatic device.

It was later found necessary to move the entire apparatus into another room, and refrigerated brine was used instead of ammonia, employing, however, the same cooling coil. The same procedure was followed with the brine; that is, allowing the brine to flow through the coil at whatever temperature it was delivered, and halancing this against heat supplied electrically and controlled by a thermostatic device.

The thermostatic device consists of a coil of copper tubing filled with toluene and connected to a $U$ tube containing mercury to make and break an electric contact. The $U$ tube is mounted on the outside of the chamber. By this method of operation the mean temperature of the cold chamber could be kept constant to about $0.5^{\circ} \mathrm{C}$., although the lag of the system distributing the heat caused the periodic fluctuations due to the make and break of the thermostat to be considerably larger than this. The period of these fluctuations, however, was usually less than one minute, and their effects were consequently not appreciable on the wall surface. It was necessary to run the fan at a fairly high speed in order to maintain a uniform temperature distribution over the test panel. 'The average velocity of the air in the space between the panel and shield was roughtly measured with a small vane anemometer and found to be of the order of 5 miles per hour. Under these conditions the temperature distribution in the air stream was uniform to a few tenths degree at all points more than about 1 inch from the surface of the panel, and over most of the area of the latter. This distribution was determined by a large number of thermocouples distributed at various points in this region.

A thin wall-board shield, with openings at top and bottom, is mounted, as shown in the figure, 6 inches from the surface of the test panel and serves to direct the air circulation from the fan up and along the face of the test panel, as well as to shield the latter from the direct influence of the cooling and heating coils.

The warm chamber is identical with the cold chamber except that it contains no cooling arrangement and no thermostat. The latter is not necessary, since a constant current from a storage battery is supplied to the heater, and all the surroundings are in a steady state. The temperature of the hot chamber can be varied by varying the current supplied to the heating coil.

The room in which all the apparatus except the refrigerating machine is located is a small insulated interior room, the temperature of which is automatically controlled by a thermostat similar to the one in the cold chamber. The temperature of the room is ordinarily 
maintained a few degrees above the rest of the building, so that no cooling is required, and only a small amount of heat supplied electrically.

\section{CONDUCTIMETER}

The comparison panel, or conductimeter, as it has been termed, consists of a thin panel of homogeneous material whose thermal conductivity is known. Two types of conductimeters were constructed. The first was made of clear white pine about three-fourths inch thick. For convenience, and to insure better thermal contact with the test panel, it was built in three sections, each about 3 by 2 feet, the edges being bound with strips to prevent warping, and the whole panel well varnished. No apparatus being available for the calibration of such a large panel, an opening 8 inches square was cut from the center and a calibrated piece of the same material inserted. The construction and calibration of this latter piece will be considered more in detail later.

A second conductimeter was made of a cork composition ${ }^{3}$ onefourth inch thick. This was also built in three sections 3 by 2 feet, and the surfaces were well varnished. An opening 8 inches square was cut from each of these sections, and a calibrated piece of the same material inserted. The advantage that this second conductimeter has over the first is that it is somewhat flexible, and by exerting pressure at various points over the surface a far better contact may be had with the test panel than can be obtained with the white pine conductimeter. In employing the cork conductimeter provision was made in the hot chamber, by means of wooden pegs and springs, to press the conductimeter against the panel.

In the construction of the center piece of white pine, two pieces of clear fine-grained white pine (pattern lumber) each 8 inches square and about one-fourth inch thick were glued together with their grain at right angles to form a permanently flat piece about one-half inch thick. Twenty-five thermocouples in series were mounted on the two sides of the board, the junctions being placed alternately on one face and the other and distributed uniformly over the surfaces. No. 36 copper and constantan wire were used for the couples, the junctions being silver soldered, and the two wires from each junction being led along the surface of the board for about an inch before being threaded through fine holes in the board. A piece of veneer was then cemented to each side of the board with soft deKhotinski cement and the conductimeter placed in a press while the cement was still soft.

The center pieces of cork were made of the same material as the rest of the conductimeter. Thermocouples made of No. 32 copper and constantan wire, five in number, were distributed evenly over each surface of the piece, and were connected in series. The surfaces were then varnished and thin tin foil was pasted over them. The putrpose of the foil was to insure constancy in the composition of the material, for it was suspected that the content of moisture or other volatile material might vary over a long period of time and change the calibration.

In each of the two conductimeters, the center piece had a number of couples in series, since it was intended to use a rather insensitive instrument, such as a potentiometer recorder or a portable potenti-

3 A cork composition made by the Armstrong Cork Co., known under the name of "Suberac.' 
ometer indicator to make the e.m.f. measurements. Each of these pieces was calibrated in a thermal conductivity apparatus described elsewhere. ${ }^{4}$ This apparatus is designed for two identical test specimens, consequently for the white-pine section it was necessary to use a slab of material of known conductivity on one side of the heating plate and calculate the heat flow through this specimen. A slab of cork board, the conductivity of which had been precisely determined, was used for this purpose. Four center pieces of the cork composition were constructed, and they were calibrated in pairs without the aid of any other material.

Calibrations were made in this apparatus at different times. Check calibrations were made under conditions of actual use by the following method: A panel was constructed of cork board, whose thermal conductivity and thickness were known. This panel was used in conjunction with the conductimeters, and a regular test was made in the large apparatus similar to a test on walls. The following results were obtained:

Average thickness of cork panel $=1.222$ inches.

Thermal conductivity (determined in hot-plate apparatus) $=0.29$ B. t. u. hr. ${ }^{-1} \mathrm{ft}^{-2}$ deg..$^{-1} \mathrm{~F}$. in.

Conductivity of cork panel as determined by conductimeter at-

\begin{tabular}{|c|c|c|c|}
\hline Date & Top & Middle & Bottom \\
\hline $\begin{array}{l}\text { Oct. } 19,1927 \\
\text { Oct. } 21,1927 \\
\text { Dec. } 13-16,1927-\end{array}$ & $\begin{array}{r}0.31 \\
.27 \\
.28\end{array}$ & $\begin{array}{r}0.32 \\
.29 \\
.30\end{array}$ & $\begin{array}{r}0.31 \\
.29 \\
.29\end{array}$ \\
\hline
\end{tabular}

These results indicate a satisfactory accord of the methods employed.

\section{WALLS 5}

No. 1. 8-inch bricle wall.-Surface clay (Baltimore) brick; American bond (headers every sixth course); plaster on one side; workmanship is of such nature that all joints (vertical and horizontal) are completely filled with mortar; built by mason A. Total thickness, 87/8 inches. See Figures 5 and 6.

The mortar of this and all other walls consists of $1: 1: 6$ Portland cement, hydrated lime, sand, by volume. The plaster of all walls consists of scratch and brown coats of 1:3 gypsum plaster (fibered) and sand; finish coat consists of $1: 1$ hydrated lime and calcined gypsum.

No. 2. 8-inch brick wall.-Very hard burned (New England) brick, formed from dense surface clay; American bond; plaster on one side; workmanship similar to wall No. 1, but built by mason. B. Total thickness, $8 \%$ inches.

No. 3. 8-inch brick wall.-Rather porous, dry-pressed (Mississippi) brick, formed from surface clay; workmanship same as for wall No. 2. Total thickness, $8 \% \frac{7}{8}$ inches.

4 Van Dusen, J. Am. Soc. Heating and Ventilating Eng., October, 1920; Am. Soc. Refrigerating Eng. J. November, 1920.

5 Three masons, A, B, and C, were employed in the construction of these walls. Masons B and C are the same as those employed in the construction of the walls for Research Paper No. 108, B. S. Jour. Research. The workmanship of mason A is similar to that of B. For a more complete description of the walls built by masons $\mathrm{B}$ and $\mathrm{C}$ the reader is referred to the above-cited paper. 
No. 4. 12-inch brick wall.-Mississippi brick; same as wall No. 3, except that the total thickness is $13 \frac{1}{4}$ inches.

No. 5. 8-inch brick wall.-Mississippi brick; differs from wall No. 3 in that the workmanship is characterized by furrowed horizontal

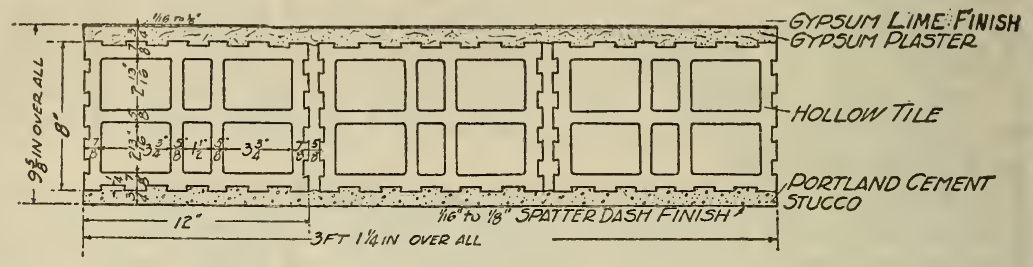

8-INCH Hollow TILE WALL (END CONSTRUCTION)

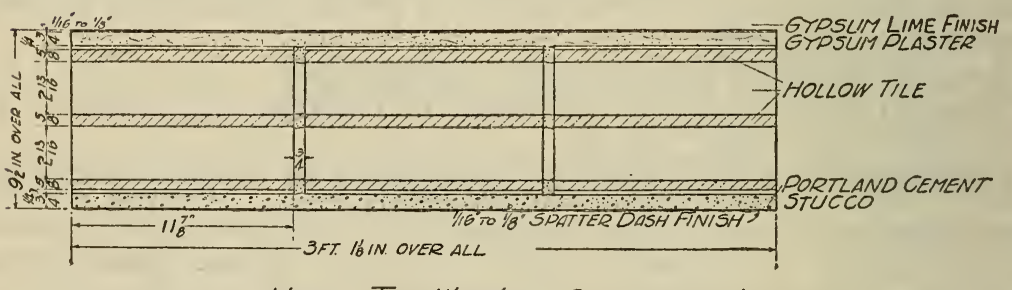

8-INCH HOLLOW TILE WALL (SIDE CONSTRUCTION)

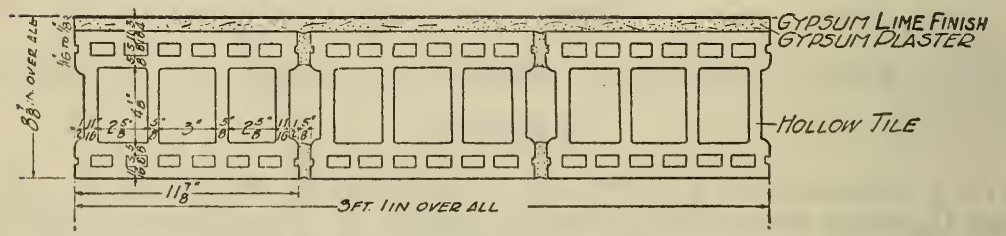

8-INCH HOLLOW TILE WALL (DOUBLE SHELL)

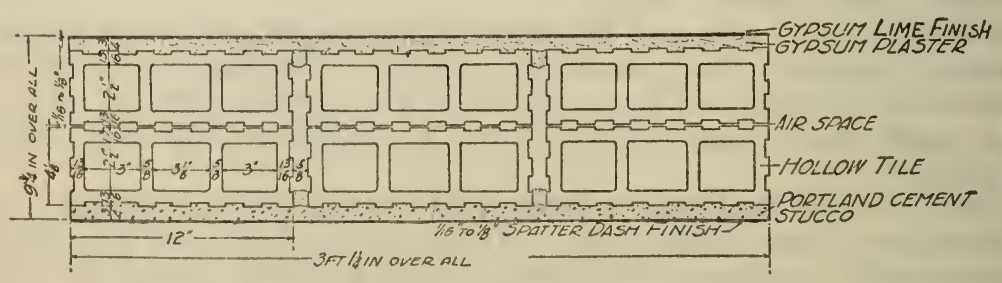

B-INCH HOLLOWTILE WALL (TWO UNIT)

Figure 5.-Horizontal cross section of test walls

joints (see fig. 7), and unfilled vertical longitudinal joints. (See fig. 8.) Built by mason C. Total thickness, $8 \% 8$ inches.

No.6. S-inch furred brick wall.-Baltimore brick; workmanship same as for wall No. 1. Furring consists of seven-eighths inch wood strips covered with expanded metal lath, making a total thickness of 
10 inches. Built by mason $A$. Total thickness $93 / 4$ inches. (See figs. 5 and 6. )

No. \%. S-inch rolokbak wall.-Mississippi brick; built by mason B; plastered on one side. Total thickness $87 \%$ inches. (See fig. 9.)

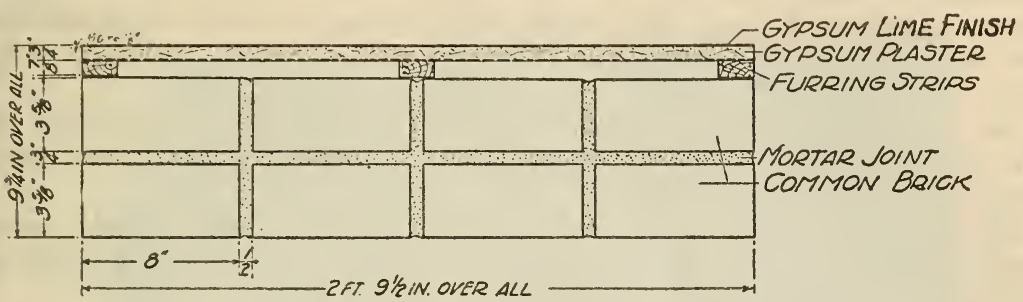

B-INCH FURRED BRICK WALL

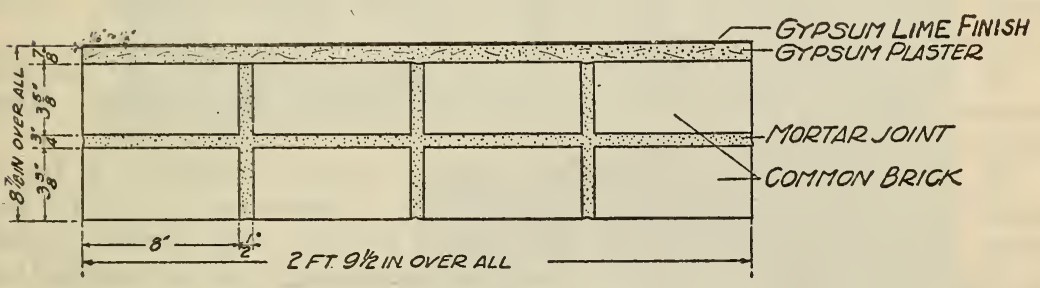

8-INCH BRICK WALL

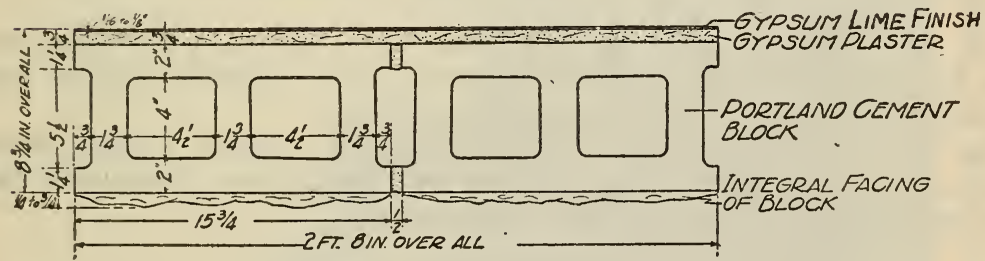

8.INCH CEMENT BLOCK WALL

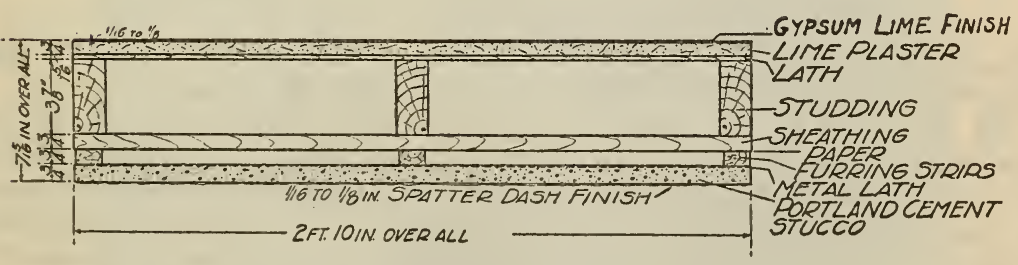

FRAME WALL

Figdre 5.-Horizontal cross section of test walls-Continued

No. 8. 8-inch all-rolok wall.-Materials and workmanship same as for wall No. 7. Total thickness $87 / 8$ inches. (See fig. 10.)

No. 9. 8-inch all-rolok wall.-Baltimore brick; built by mason A; otherwise similar to wall No. 8 . 
No. 10. 8-inch hollow tile (end construction). -8 by 12 by 12 inch XXX load-bearing, dense fire clay tile, set with cells vertical; inside, plastered; outside, stucco; total thickness $9 \% \frac{5}{8}$ inches. (See figs. 5 and 11.)

Outside surface consists of scratch coat of $1: 1 / 10: 21 / 2$ Portland cement, hydrated lime, and sand; stucco coat of same composition. This last coat is what is known as spatter dash, giving a very rough surface.

No. 11. 8-inch hollow tile (side consiruction).--Same as wall No. 10, but with tile set with cells horizontal. Total thickness $9 \frac{1}{2}$ inch. (See figs. 5 and 11.)

No. 12. 8-inch hollow tile (double shell). -5 by 8 by 12 inch dense fire clay, double shell, load bearing tile; cells vertical, and plaster on one side. Total thickness $8 \%$ inches. (See fig. 5.)

No. 13. 8-inch hollow tile (two unit). -4 by 12 by 12 inch three-cell, dense fire clay, load bearing tile; set side by side with cells vertical; bonded with metal ties; plaster on one side, stucco on other. Total thikness $93 / 4$ inches. (See fig. 5.)

No. 14. 8-inch Portland cement-sand block. -6 by 8 by 12 inch two-cell block, set with cells vertical, and plaster on one side. Total thickness $8 \frac{3}{4}$ inches. (See fig. 5.)

No. 15. 4-inch frame. - Studs, 2 by 4 inches (actually 2 by $3 \frac{5 / 8}{8}$ inches), spaced 16 inches between centers; plaster on $5 / 16$ by $1 \frac{3}{8}$ inch white pine lath; white pine sheathing, $1 \frac{3}{16}$ by $11 \frac{5}{8}$ inches, spaced one-eighth inch apart, and covered with asphalt saturated roofing felt; furring strips, $3 / 4$ by $1 \frac{112}{2}$ inches, spaced 16 inches between centers, set vertically, forming an air space three-fourths inch width; stucco applied to expanded metal lath. Total thickness $75 / 16$ inches. (See fig. 5.)

No. 16. 4-inch frame.- Same as wall No. 15, except that the stucco and furring strips were removed, leaving lath, plaster, 2 by 4 studs, sheathing and paper.

No. 17. Air space.-Air space formed by wooden frame; interior dimensions, $277 / 8$ by $65 \%$ by $7^{13 / 16}$ inches, the largest dimension being vertical; walls formed of compo wall board.

Data on compo wall board

Thickness of single sheet $=0.26$ inch.

Conductance $\ldots . . . . .63$ B. t. u. hr..$^{-1} \mathrm{ft}^{-2}$ deg. ${ }^{-1} \mathrm{~F}$.

Resistance........... $=.38$.

The resistances of the two thicknesses of compo board have been allowed for in calculating the resistance of the rir space.

All the panels were seasoned inside the building from two to four months before testing. During construction, copper-constantan thermocouples of No. 28 wire were placed at a large number of points in the interior, as well as on the surfaces of each panel. The inside surface of each panel was given a thin finishing coat of plaster to make the surfaces reasonably flat. The conductimeter panel was placed on the warmer side in contact with this surface, so that the irregularities of contact thermal resistance would be small.

\section{OPERATION}

The measurements of e. m. f. of the thermocouples were made with a portable potentiometer and a potentiometer recorder. The latter 


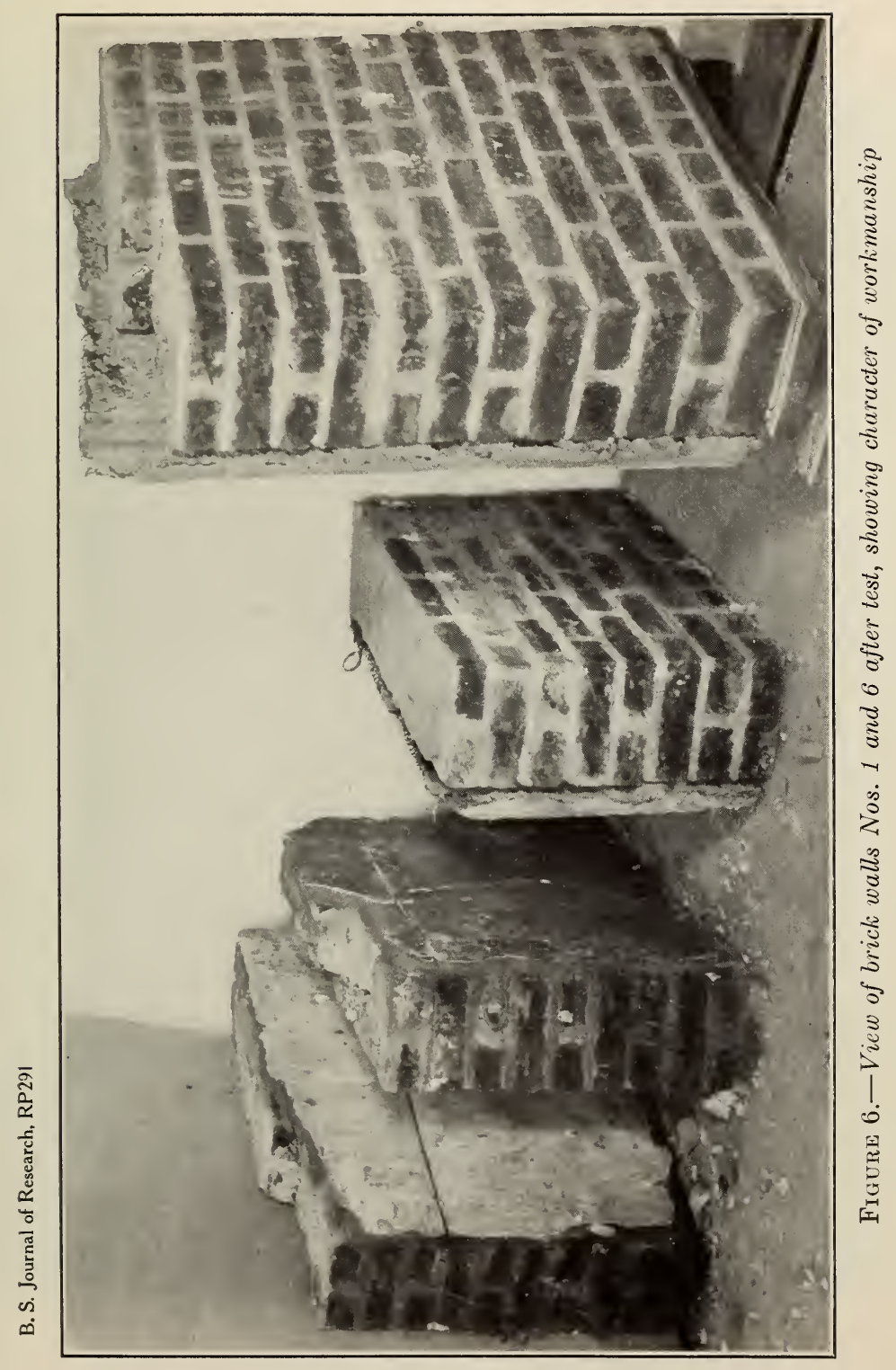


B. S. Journal of Research, RP291

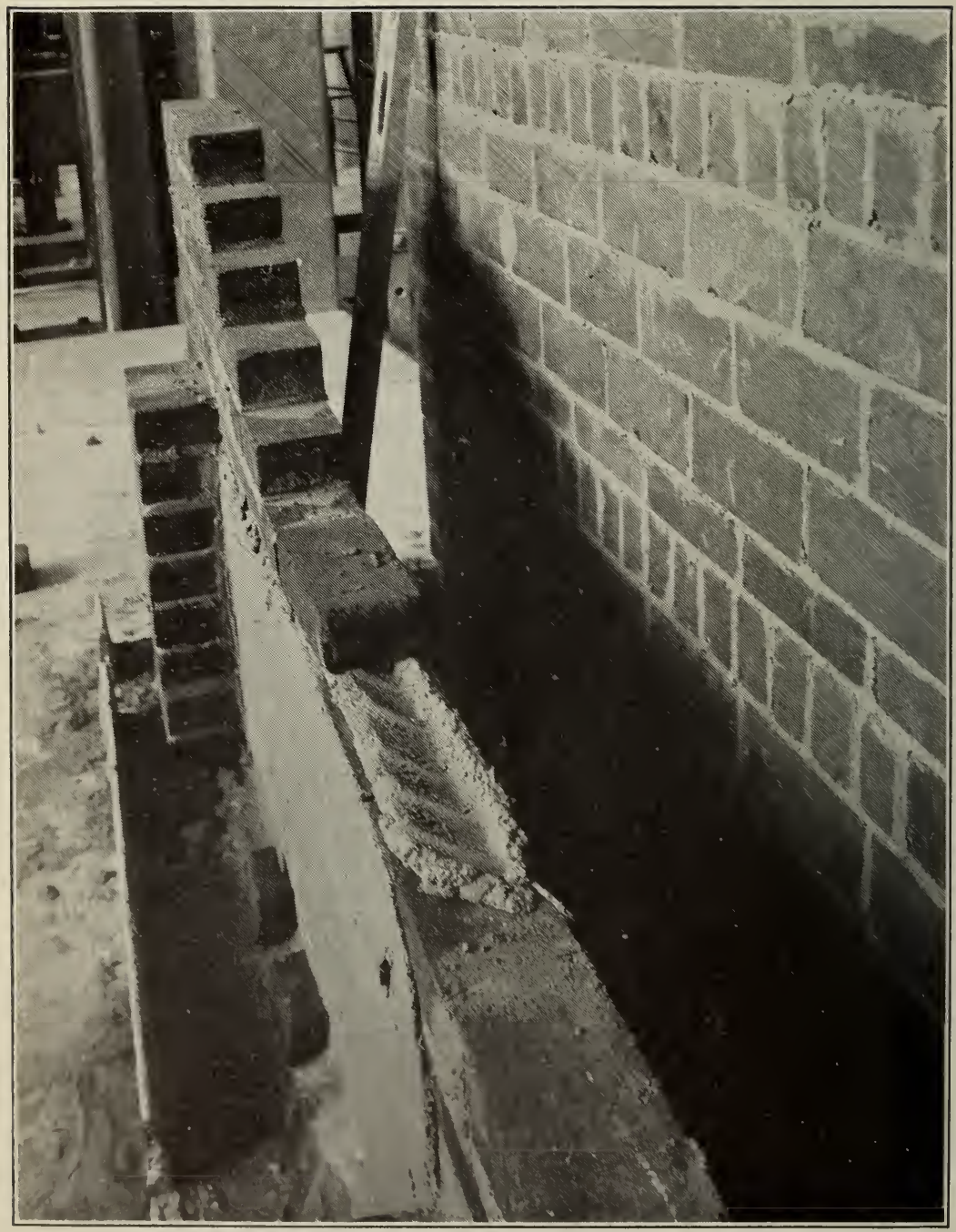

FInURE 7.-Viell shouring furroued horizontal joints 
B. S. Journal of Research, RP29|

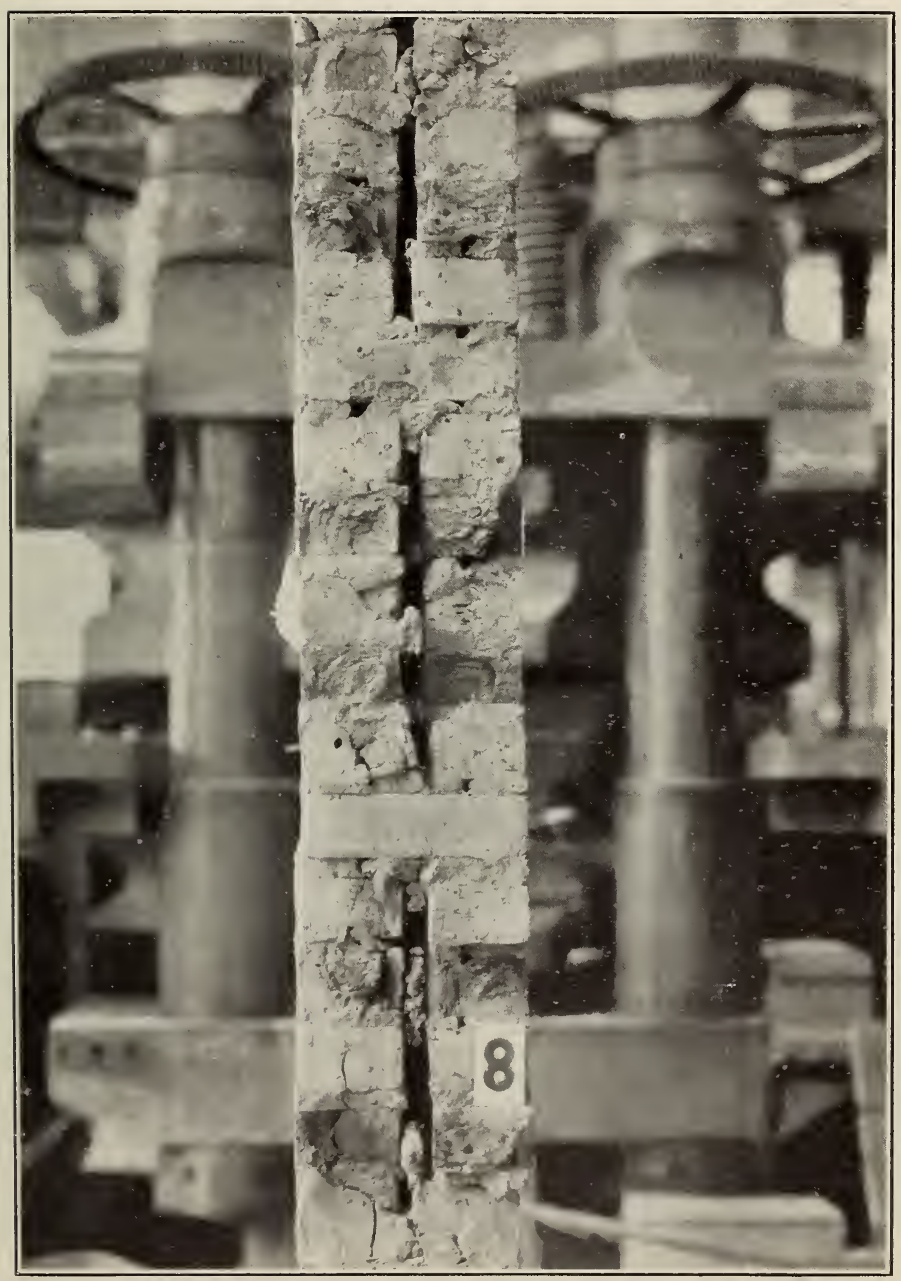

FIGURE 8.-View showing unfilled vertical joints 


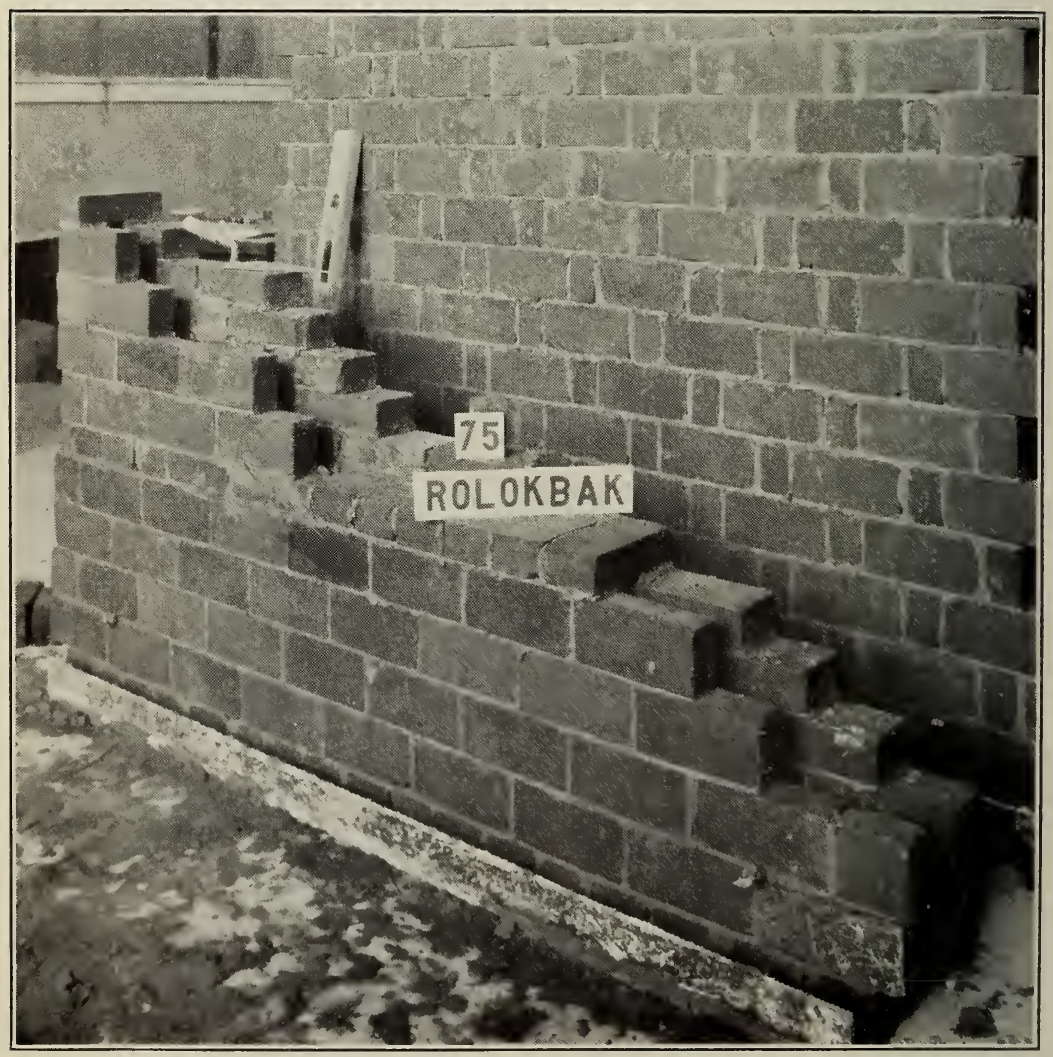

Figure 9.-Wall identical with No. $\gamma$ in process of construction 


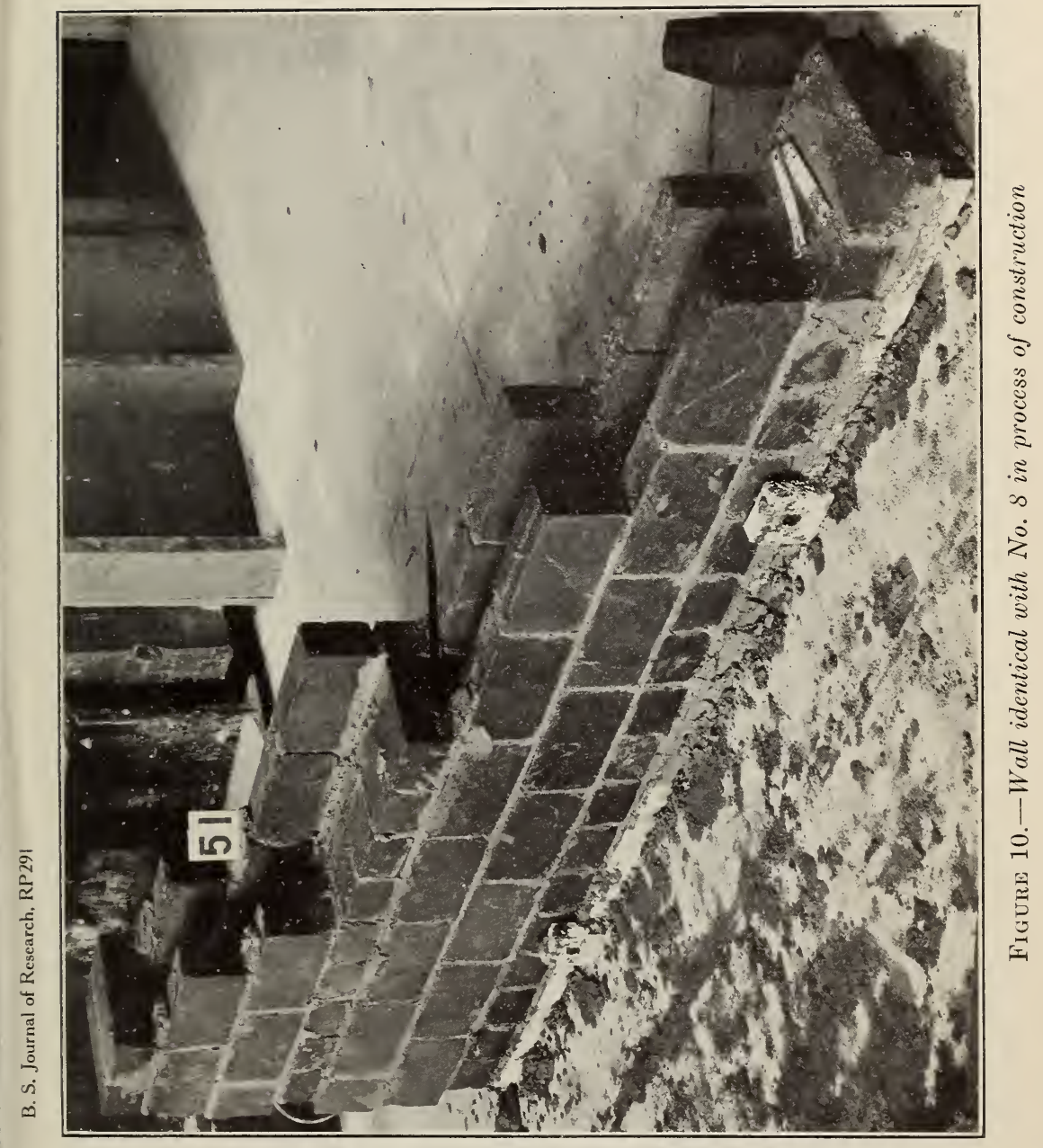




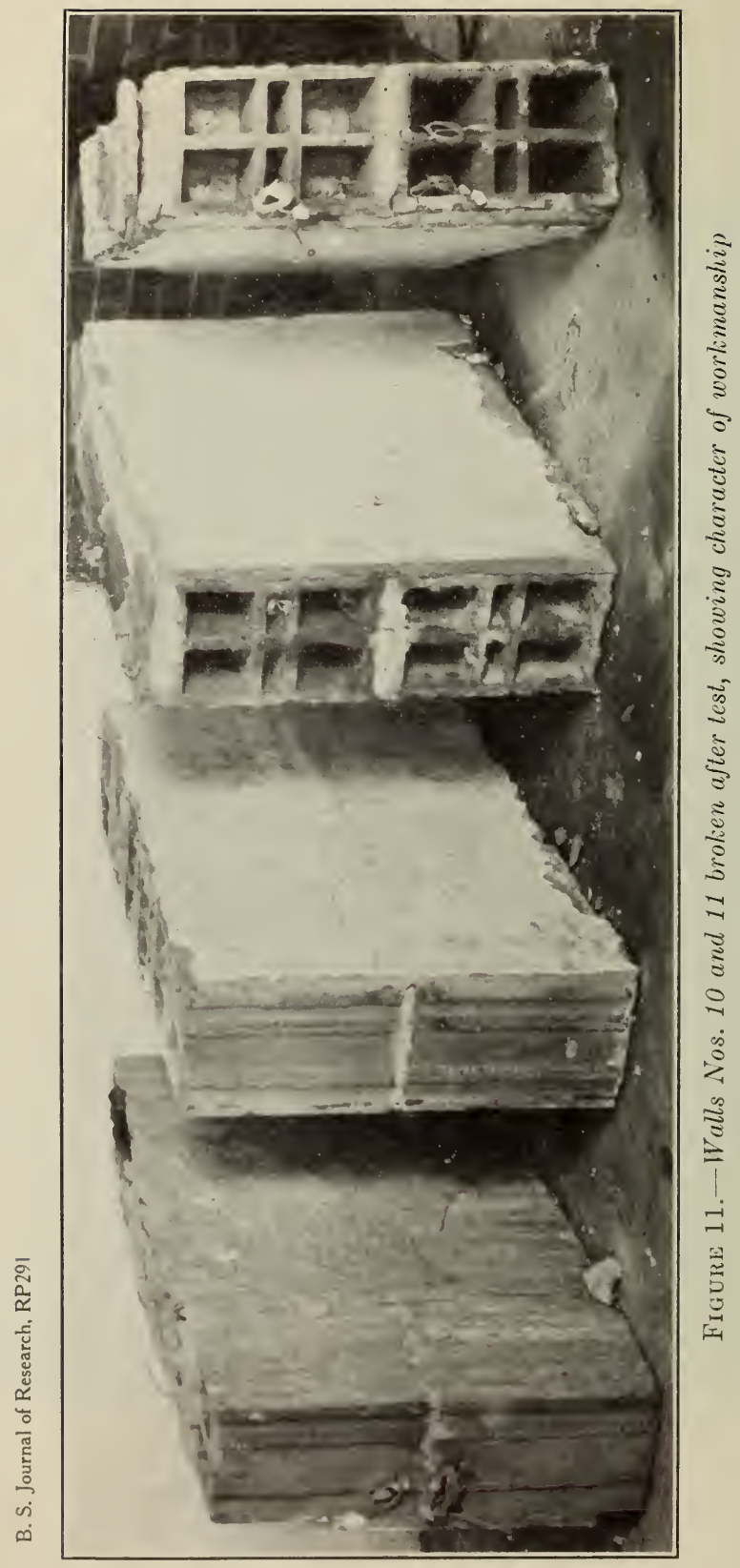


was used only to indicate whether or not conditions had been steady during the night or between readings on the portable potentiometer. Readings could be made with an accuracy of about 0.02 millivolt, corresponding to about $1^{\circ} \mathrm{F}$. on a single thermocouple. The regulation of temperature was not precise enough to warrsnt greater precision in reading. Most of the panels required about 48 hours to come to a sufficiently steady state, but the experiment was always continued more than two days if possible, in order to make certain that the system actually was in a steady state. It was found that large errors were likely to occur if the experimental conditions were not steady for long periods. A good many runs were terminated or disturbed by the accidental failure of one or more of the control devices. In many of these, the conditions seemed fairly steady before the accident happened, but the calculated results sometimes showed differences as large as 20 per cent from those obtained under better conditions.

\section{RESULTS AND DISCUSSION}

It is to be borne in mind that the results presented in this paper are for particular specimens. Although the relative values for several types of construction may be considered fairly precise, it is quite probable that similar constructions in practice may differ to an appreciable extent from those tested here. Doubtless, quality of workmanship will be an important factor. To demonstrate this, two similar brick walls (Nos. 3 and 5) were built by different masons, and, as will be noted below, a difference of about 30 per cent in their insulating values was observed. These two specimens may possibly characterize the two extremes in workmanship. Therefore, in judging the absolute magnitude of the heat transfers, allowances must be made for such variations.

Results were obtained both with wood and cork conductimeters. An appreciable difference was found by these two conductimeters, but the results with the cork conductimeter were found to be much more consistent and reproducible.

These differences in behavior are not difficult to explain, and it seems desirable to discuss the question somewhat in detail, since points vital to the accuracy of this general method of measuring heat flow are involved.

It is quite evident that errors due to lateral heat flow in the system will be produced by a nonuniform or poor thermal contact between the conductimeter and the surface to which it is applied. If the contact consists of an air space of variable width, two distinct sources of error are present. The nonuniformity of contact causes a departure from normal heat flow within the conductimeter itself (the condition under which it was calibrated) and convection in the air space also causes heat flow in directions other than those perpendicular to the faces of the panels. At first it was thought that the contact between the wood conductimeter and the flat plaster surface would be sufficiently good, but due to the inconsistency of the results obtained, it was decided to build a more flexible conductimeter panel and provide means for pressing it firmly against the plaster surface at a large number of points. As mentioned above, the results obtained with the new conductimeter were reproducible with much greater precision than the old, and in addition were somewhat lower, as might be 
expected since both of the sources of error mentioned above are more likely to cause too high a value for the calculated conductance of the panel. The fact that the thermal contact between the cork conductimeter and plaster surface was extremely good is indicated by the small temperature difference, averaging about $1^{\circ} \mathrm{F}$., existing between the surfaces in contact. With the wood conductimeter the corresponding temperature differences were variable and much greater. It does not seem possible that the slightly better thermal contact which might be produced by cementing the surfaces together would have changed the results by any significant amount.

For the above reasons the data given in this paper are based entirely on the experiments made with the cork conductimeter. Calibrations of the conductimeter were made at frequent intervals.

TABLE 1.-Calibration of cork composition conductimeler

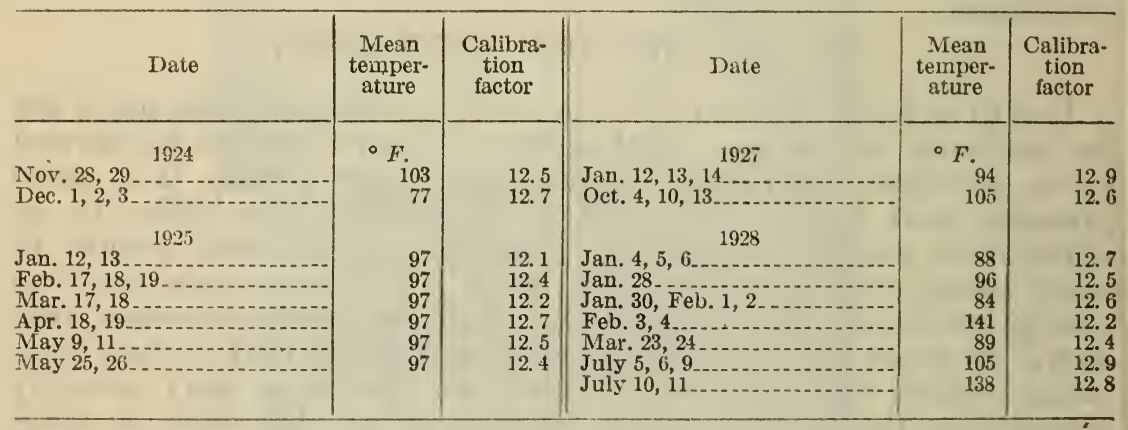

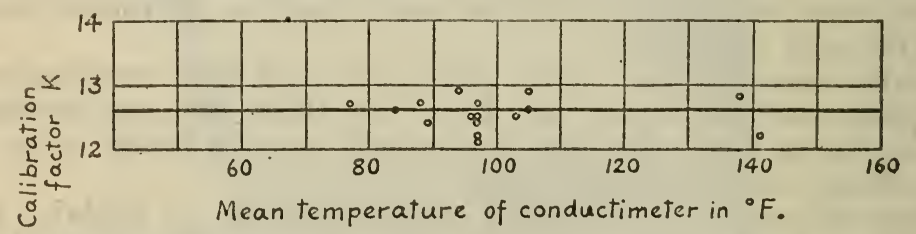

FIgURE 12.-Calibration of cork composition conductimeters

Table 1 gives the complete calibration data. In the second column is given the mean temperature of the conductimeter, and in the last column the calibration factor, which is the number of $\mathrm{B}$. t. $\mathrm{u}$. flowing through the conductimeter per hour, per square foot, per millivolt reading of the imbedded differential thermocouples. The fluctuations in the calibration factor are due probably to changes in the moisture content of the cork composition, a factor which is difficult to control. However, for all practical purposes an average value taken over a long period of time is sufficiently accurate for the purpose at hand. The conductivity of the cork composition increases with mean temperature, but this is practically compensated by a corresponding increase in the e. $\mathrm{m}$. f. per degree of the copper-constantan couple used. The resultant effect is to yield a calibration factor which is practically independent of the mean temperature as shown in Figure 12. 
Table 2 gives the complete data for all the walls tested. In the last column is given the resistance per unit area, which is the reciprocal of the conductance per unit area. The conductances and resistances do not include any surface effects. The mean temperature given in column 6 is the mean of the temperatures of the warm and cold surfaces of each wall.

All the curves in Figure 13 show, as would be expected, a decrease in resistance with increase in mean temperature. The slopes of the curves for the 8 -inch solid walls are about what might be expected, judging from our rather scanty knowledge of the increase in conductivity with temperature of such materials as brick. The slopes of the curves for walls containing air spaces are naturally greater, on account of the very rapid increase in the heat transfer by radiation. In some cases, however, for example, walls No. 9, 11, 15, 16, and 17 the slopes are greater than can be accounted for by any known facts of radiation, conduction, or convection. A single case of this kind could easily be explained as fortuitous experimental error, but the effect appears to be systematic, and such an explanation for all cases is therefore improbable. It will be noted that the direction of the effect is such that it could be accounted for, qualitatively at least, by lateral heat flow in the wall specimen, resulting from exchange of heat between the edges of the specimen and the test room which was always maintained at nearly the same temperature during all tests on a single wall section. The measured resistances at mean temperatures below that of the test room would tend to be too high, and those at mean temperatures above that of the test room, too low.

TABLE 2.

\begin{tabular}{|c|c|c|c|c|c|c|c|c|c|}
\hline Wall & Description & $\begin{array}{l}\text { Tem- } \\
\text { nera- } \\
\text { ture of } \\
\text { warm } \\
\text { air }\end{array}$ & $\begin{array}{c}\text { Tem- } \\
\text { pera- } \\
\text { ture of } \\
\text { cold } \\
\text { air }\end{array}$ & $\begin{array}{l}\text { Tem- } \\
\text { pera- } \\
\text { ture of } \\
\text { plaster } \\
\text { or warm } \\
\text { surface } \\
\text { of wall }\end{array}$ & $\begin{array}{l}\text { Tem- } \\
\text { pera- } \\
\text { ture of } \\
\text { cold } \\
\text { surface } \\
\text { of wall }\end{array}$ & $\begin{array}{c}\text { Mean } \\
\text { tem- } \\
\text { pera- } \\
\text { ture of } \\
\text { wall }\end{array}$ & $\begin{array}{l}\text { E. m. f. } \\
\text { of con- } \\
\text { ducti- } \\
\text { meter }\end{array}$ & $\begin{array}{l}\text { Con- } \\
\text { duct- } \\
\text { ance of } \\
\text { wall }\end{array}$ & $\begin{array}{l}\text { Resist- } \\
\text { ance of } \\
\text { wall }\end{array}$ \\
\hline No. 1. & 8-inch brick (Baltimore) & $\begin{array}{r}\circ F . \\
56.9 \\
105.6 \\
92.5 \\
79.6\end{array}$ & $\begin{array}{r}\circ F . \\
1.3 \\
42.7 \\
28.1 \\
15.5\end{array}$ & $\begin{array}{l}\circ F . \\
38.5 \\
83.7 \\
70.5 \\
58.7\end{array}$ & $\begin{array}{c}\circ F . \\
10.1 \\
52.0 \\
37.6 \\
26.8\end{array}$ & $\begin{array}{r}\circ F \\
24.3 \\
67.8 \\
54.1 \\
42.8\end{array}$ & $\begin{array}{c}\text { Milli- } \\
\text { volis } \\
1.32 \\
1.61 \\
1.63 \\
1.57\end{array}$ & $\begin{array}{l}\text { B.t. } u \text {. } \\
\text { per } h r . \\
\text { per sq. } \\
\text { per }{ }^{\circ} \text {. } \\
0.585 \\
.64 \\
.62 \\
.62\end{array}$ & $\begin{array}{r}\circ F . l \\
\text { B.t.u. } \\
\text { per hr. } \\
\text { persq.ft } \\
1.71 \\
1.56 \\
1.60 \\
1.60\end{array}$ \\
\hline No. 2. & 8-inch brick (New England) & $\begin{array}{r}75.5 \\
56.6 \\
92.3 \\
113.8 \\
87.6 \\
80.6 \\
117.8 \\
126.6\end{array}$ & $\begin{array}{l}21.2 \\
15.3 \\
37.9 \\
49.7 \\
21.4 \\
15.9 \\
37.7 \\
32.4\end{array}$ & $\begin{array}{l}53.8 \\
41.7 \\
72.9 \\
91.3 \\
62.4 \\
54.9 \\
85.9 \\
90.0\end{array}$ & $\begin{array}{l}32.4 \\
24.9 \\
52.4 \\
65.8 \\
35.2 \\
28.4 \\
53.3 \\
49.8\end{array}$ & $\begin{array}{l}43.1 \\
33.3 \\
62.7 \\
78.5 \\
48.8 \\
41.7 \\
69.6 \\
69.9\end{array}$ & $\begin{array}{l}1.52 \\
1.05 \\
1.45 \\
1.70 \\
1.81 \\
1.95 \\
2.46 \\
2.79\end{array}$ & $\begin{array}{l}.90 \\
.79 \\
.89 \\
.84 \\
.84 \\
.93 \\
.95 \\
.87\end{array}$ & $\begin{array}{l}1.11 \\
1.26 \\
1.12 \\
1.19 \\
1.19 \\
1.08 \\
1.05 \\
1.14\end{array}$ \\
\hline No. 3. & 8-inch brick (Mississippi) ... & $\begin{array}{r}121.8 \\
86.6\end{array}$ & $\begin{array}{l}34.2 \\
23.7\end{array}$ & $\begin{array}{l}89.8 \\
63.6\end{array}$ & $\begin{array}{l}51.3 \\
37.4\end{array}$ & $\begin{array}{l}70.6 \\
50.5\end{array}$ & $\begin{array}{l}2.33 \\
1.56\end{array}$ & $\begin{array}{l}.76 \\
.75\end{array}$ & $\begin{array}{l}1.31 \\
1.33\end{array}$ \\
\hline No. 4 & 12-inch brick... & $\begin{array}{r}82.9 \\
128.5 \\
80.2\end{array}$ & $\begin{array}{l}21.9 \\
42.4 \\
17.2\end{array}$ & $\begin{array}{l}64.5 \\
98.5 \\
61.4\end{array}$ & $\begin{array}{l}33.8 \\
54.6 \\
29.2\end{array}$ & $\begin{array}{l}49.1 \\
76.6 \\
45.3\end{array}$ & $\begin{array}{l}1.22 \\
2.12 \\
1.26\end{array}$ & $\begin{array}{l}.50 \\
.61 \\
.49\end{array}$ & $\begin{array}{l}2.00 \\
1.64 \\
2.03\end{array}$ \\
\hline No. $5 \ldots$ & 8-inch brick... & $\begin{array}{r}131.1 \\
90.6\end{array}$ & $\begin{array}{l}48.1 \\
24.7\end{array}$ & $\begin{array}{r}101.1 \\
68.3\end{array}$ & $\begin{array}{l}58.8 \\
35.2\end{array}$ & $\begin{array}{l}80.0 \\
51.7\end{array}$ & $\begin{array}{l}2.00 \\
1.41\end{array}$ & $\begin{array}{l}.595 \\
.55\end{array}$ & $\begin{array}{l}1.68 \\
1.82\end{array}$ \\
\hline No. 6. & 8-inch furred brick.. & $\begin{array}{r}110.5 \\
68.0 \\
65.5 \\
105.1\end{array}$ & $\begin{array}{r}31.1 \\
5.0 \\
-4.4 \\
43.5\end{array}$ & $\begin{array}{l}90.0 \\
52.9 \\
48.7 \\
87.8\end{array}$ & $\begin{array}{r}43.9 \\
15.1 \\
5.9 \\
52.0\end{array}$ & $\begin{array}{l}67.0 \\
34.0 \\
27.3 \\
69.9\end{array}$ & $\begin{array}{l}1.49 \\
1.07 \\
1.18 \\
1.21\end{array}$ & $\begin{array}{l}.41 \\
.36 \\
.35 \\
.425\end{array}$ & $\begin{array}{l}2.45 \\
2.80 \\
2.88 \\
2.35\end{array}$ \\
\hline
\end{tabular}


TABLE 2.-Continued

\begin{tabular}{|c|c|c|c|c|c|c|c|c|c|}
\hline Wall & Description & $\begin{array}{l}\text { Tem- } \\
\text { pera- } \\
\text { ture of } \\
\text { warm } \\
\text { air }\end{array}$ & $\begin{array}{l}\text { Tem- } \\
\text { pera- } \\
\text { ture of } \\
\text { cold } \\
\text { air }\end{array}$ & \begin{tabular}{|} 
Tem- \\
pera- \\
ture of \\
plaster \\
or warm \\
surface \\
of wall
\end{tabular} & $\begin{array}{c}\text { Tem- } \\
\text { pera- } \\
\text { ture of } \\
\text { cold } \\
\text { surface } \\
\text { of wall }\end{array}$ & $\begin{array}{l}\text { Mean } \\
\text { tem- } \\
\text { pera- } \\
\text { ture of } \\
\text { wall }\end{array}$ & $\begin{array}{l}\text { E. m.f. } \\
\text { of con- } \\
\text { ducti- } \\
\text { meter }\end{array}$ & $\begin{array}{l}\text { Con- } \\
\text { duct- } \\
\text { ance of } \\
\text { wall }\end{array}$ & $\begin{array}{c}\text { Resist- } \\
\text { ance of } \\
\text { wall }\end{array}$ \\
\hline No. $7 \ldots$ & 8-inch rolokbak-... & $\begin{array}{r}\circ F . \\
134.6 \\
86.9 \\
86.5\end{array}$ & $\begin{array}{c}{ }^{\circ} F . \\
49.1 \\
27.4 \\
31.3\end{array}$ & $\begin{array}{r}\circ F . \\
106.8 \\
69.3 \\
69.7\end{array}$ & $\begin{array}{c}{ }^{\circ} F \\
61.0 \\
36.4 \\
38.8\end{array}$ & $\begin{array}{l}{ }^{\circ} F . \\
83.9 \\
52.9 \\
54.2\end{array}$ & $\begin{array}{c}\text { Milli- } \\
\text { volts } \\
1.99 \\
1.21 \\
1.19\end{array}$ & $\begin{array}{c}\text { B.t.u. } \\
\text { per } h r . \\
\text { per sq. } \\
\text { per } 0 \text {. } \\
0.55 \\
.46 \\
.485\end{array}$ & \begin{tabular}{|r}
$\circ F . l$ \\
B.t.u. \\
per hr. \\
persq.ft. \\
1.83 \\
2.16 \\
2.06
\end{tabular} \\
\hline No. 8 .. & 8-inch all rolok....... & $\begin{array}{r}147.8 \\
87.7 \\
90.0\end{array}$ & $\begin{array}{l}51.2 \\
25.7 \\
34.0\end{array}$ & $\begin{array}{r}115.1 \\
68.1 \\
72.3\end{array}$ & $\begin{array}{l}64.3 \\
36.2 \\
42.6\end{array}$ & $\begin{array}{l}89.7 \\
52.2 \\
57.5\end{array}$ & $\begin{array}{l}2.51 \\
1.39 \\
1.31\end{array}$ & $\begin{array}{l}.62 \\
.55 \\
.555\end{array}$ & $\begin{array}{l}1.61 \\
1.82 \\
1.80\end{array}$ \\
\hline No. $9 \ldots$ & 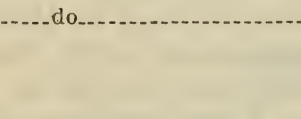 & $\begin{array}{r}119.4 \\
82.6 \\
81.2 \\
121.0 \\
125.1\end{array}$ & $\begin{array}{l}51.4 \\
33.1 \\
30.7 \\
55.1 \\
58.7\end{array}$ & $\begin{array}{r}95.3 \\
68.0 \\
66.1 \\
97.5 \\
101.7\end{array}$ & $\begin{array}{l}58.5 \\
39.9 \\
38.9 \\
61.3 \\
65.4\end{array}$ & $\begin{array}{l}76.9 \\
54.0 \\
52.5 \\
79.4 \\
83.6\end{array}$ & $\begin{array}{l}1.81 \\
1.05 \\
1.07 \\
1.81 \\
1.85\end{array}$ & $\begin{array}{l}0.62 \\
.47 \\
.495 \\
.63 \\
.64\end{array}$ & $\begin{array}{l}1.61 \\
2.12 \\
2.02 \\
1.59 \\
1.56\end{array}$ \\
\hline No. 10 . & $\begin{array}{l}\text { 8-inch hollow tile (end con- } \\
\text { struction). }\end{array}$ & $\begin{array}{r}67.8 \\
84.0 \\
113.6\end{array}$ & $\begin{array}{r}8.1 \\
22.3 \\
46.1\end{array}$ & $\begin{array}{l}52.0 \\
67.1 \\
94.9\end{array}$ & $\begin{array}{l}14.2 \\
27.9 \\
52.8\end{array}$ & $\begin{array}{l}33.1 \\
47.5 \\
73.8\end{array}$ & $\begin{array}{l}1.06 \\
1.19 \\
1.38\end{array}$ & $\begin{array}{r}0.35 \\
.38 \\
.41\end{array}$ & $\begin{array}{l}2.83 \\
2.62 \\
2.42\end{array}$ \\
\hline No. 11 . & $\begin{array}{l}\text { 8-inch hollow tile (side con- } \\
\text { struction). }\end{array}$ & $\begin{array}{r}68.9 \\
92.5 \\
91.2 \\
109.4\end{array}$ & $\begin{array}{l}11.6 \\
31.8 \\
32.2 \\
40.6\end{array}$ & $\begin{array}{l}54.5 \\
73.8 \\
73.6 \\
87.8\end{array}$ & $\begin{array}{l}20.5 \\
38.7 \\
38.5 \\
48.4\end{array}$ & $\begin{array}{l}37.5 \\
56.2 \\
56.0 \\
68.1\end{array}$ & $\begin{array}{l}\text { 1. } 03 \\
\text { 1. } 25 \\
1.20 \\
1.49\end{array}$ & $\begin{array}{r}0.38 \\
.45 \\
.43 \\
.48\end{array}$ & $\begin{array}{l}2.62 \\
2.23 \\
2.32 \\
2.10\end{array}$ \\
\hline No. 12 & $\begin{array}{l}\text { 8-inch hollow tile (double } \\
\text { shell). }\end{array}$ & $\begin{array}{r}73.0 \\
92.6 \\
122.9\end{array}$ & $\begin{array}{l}22.0 \\
44.2 \\
63.4\end{array}$ & $\begin{array}{r}58.4 \\
77.9 \\
104.6\end{array}$ & $\begin{array}{l}27.8 \\
49.0 \\
69.6\end{array}$ & $\begin{array}{l}43.1 \\
63.4 \\
87.1\end{array}$ & $\begin{array}{l}1.02 \\
1.06 \\
1.41\end{array}$ & $\begin{array}{r}0.42 \\
.46 \\
.51\end{array}$ & $\begin{array}{l}2.38 \\
2.16 \\
1.97\end{array}$ \\
\hline No. 13 & 8-inch hollow tile (two unit) & $\begin{array}{r}76.1 \\
95.9 \\
122.9\end{array}$ & $\begin{array}{l}17.2 \\
32.0 \\
47.3\end{array}$ & $\begin{aligned} 60.8 \\
77.6 \\
100.9\end{aligned}$ & $\begin{array}{l}21.4 \\
36.7 \\
52.7\end{array}$ & $\begin{array}{l}41.1 \\
57.1 \\
76.8\end{array}$ & $\begin{array}{l}\text { 1. } 025 \\
1.22 \\
1.50\end{array}$ & $\begin{array}{r}0.33 \\
.38 \\
.39\end{array}$ & $\begin{array}{l}3.05 \\
2.66 \\
2.56\end{array}$ \\
\hline No. 14 & 8-inch cement bloek -..... & $\begin{array}{r}99.0 \\
97.7 \\
53.8 \\
114.3\end{array}$ & $\begin{array}{r}32.9 \\
30.2 \\
0.3 \\
59.6\end{array}$ & $\begin{array}{l}70.3 \\
67.8 \\
29.2 \\
91.6\end{array}$ & $\begin{array}{r}38.1 \\
34.4 \\
3.8 \\
63.2\end{array}$ & $\begin{array}{l}54.2 \\
51.1 \\
16.5 \\
77.4\end{array}$ & $\begin{array}{l}1.96 \\
2.03 \\
1.45 \\
1.64\end{array}$ & $\begin{array}{c}0.77 \\
.765 \\
.72 \\
.73\end{array}$ & $\begin{array}{l}1.30 \\
1.31 \\
1.39 \\
1.38\end{array}$ \\
\hline \multirow[t]{3}{*}{ No. 15 . } & 4-inch frame (furred) ... & $\begin{array}{r}104.7 \\
102.0 \\
94.0 \\
71.6\end{array}$ & $\begin{array}{l}66.9 \\
56.6 \\
49.0 \\
20.5\end{array}$ & $\begin{array}{l}95.7 \\
92.6 \\
84.8 \\
62.8\end{array}$ & $\begin{array}{l}72.6 \\
62.9 \\
54.7 \\
25.0\end{array}$ & $\begin{array}{l}84.1 \\
77.8 \\
69.8 \\
43.9\end{array}$ & $\begin{array}{c}0.66 \\
.745 \\
.69 \\
.69\end{array}$ & $\begin{array}{r}0.36 \\
.32 \\
.29 \\
.23\end{array}$ & $\begin{array}{l}\text { 2. } 79 \\
\text { 3. } 16 \\
\text { 3. } 48 \\
4.37\end{array}$ \\
\hline & & $\begin{array}{r}108.1 \\
90.5 \\
96.2 \\
69.2\end{array}$ & $\begin{array}{l}58.8 \\
40.3 \\
52.7 \\
20.4\end{array}$ & $\begin{array}{l}97.8 \\
81.0 \\
88.3 \\
62.2\end{array}$ & $\begin{array}{l}66.5 \\
45.6 \\
63.1 \\
26.2\end{array}$ & $\begin{array}{l}82.2 \\
63.3 \\
75.7 \\
44.2\end{array}$ & $\begin{array}{l}.79 \\
.76 \\
.65 \\
.63\end{array}$ & $\begin{array}{l}.32 \\
.27 \\
.33 \\
.22\end{array}$ & $\begin{array}{l}\text { 3. } 13 \\
\text { 3. } 69 \\
\text { 3. } 07 \\
4.55\end{array}$ \\
\hline & & $\begin{array}{r}112.3 \\
74.9 \\
128.2 \\
130.8\end{array}$ & $\begin{array}{l}47.1 \\
15.7 \\
92.0 \\
95.0\end{array}$ & $\begin{array}{r}100.2 \\
62.6 \\
119.7 \\
122.0\end{array}$ & $\begin{array}{l}62.2 \\
22.5 \\
94.0 \\
97.3\end{array}$ & $\begin{array}{r}81.2 \\
42.5 \\
10 C .9 \\
109.7\end{array}$ & $\begin{array}{l}.90 \\
.68 \\
.695 \\
.69\end{array}$ & $\begin{array}{l}.30 \\
.21 \\
.34 \\
.35\end{array}$ & $\begin{array}{l}3.36 \\
4.66 \\
2.94 \\
2.86\end{array}$ \\
\hline No. 16 . & 4-inch frame... & $\begin{array}{r}130.5 \\
80.5 \\
93.3 \\
77.2\end{array}$ & $\begin{array}{l}72.3 \\
35.0 \\
53.9 \\
31.7\end{array}$ & $\begin{array}{r}115.2 \\
71.5 \\
83.3 \\
67.0\end{array}$ & $\begin{array}{l}79.1 \\
41.2 \\
59.0 \\
36.9\end{array}$ & $\begin{array}{l}97.2 \\
56.3 \\
71.1 \\
52.0\end{array}$ & $\begin{array}{l}1.18 \\
0.68 \\
0.705 \\
.685\end{array}$ & $\begin{array}{r}0.41 \\
.25 \\
.37 \\
.29\end{array}$ & $\begin{array}{l}2.43 \\
\text { 3. } 54 \\
\text { 2. } 73 \\
\text { 3. } 49\end{array}$ \\
\hline No. 17 . & Air space..... & $\begin{array}{r}120.4 \\
73.9 \\
90.8\end{array}$ & $\begin{array}{l}56.8 \\
30.6 \\
46.6\end{array}$ & $\begin{array}{l}97.5 \\
60.3 \\
75.6\end{array}$ & $\begin{array}{l}66.6 \\
37.3 \\
52.7\end{array}$ & $\begin{array}{l}82.1 \\
48.8 \\
64.1\end{array}$ & $\begin{array}{l}1.63 \\
.92 \\
1.05\end{array}$ & $\begin{array}{l}0.66 \\
.505 \\
.58\end{array}$ & $\begin{array}{l}1.51 \\
1.98 \\
1.73\end{array}$ \\
\hline
\end{tabular}

In considering the lateral heat flow by conduction in a solid wall, only the width and thickness have to be considered as a first approximation, since the specimens are twice as tall as they are wide. If the mean temperature of the wall differs from that of the test room, the temperature distribution in the central region will be affected to some extent. For a 9-inch solid wall, however, it can be shown by 


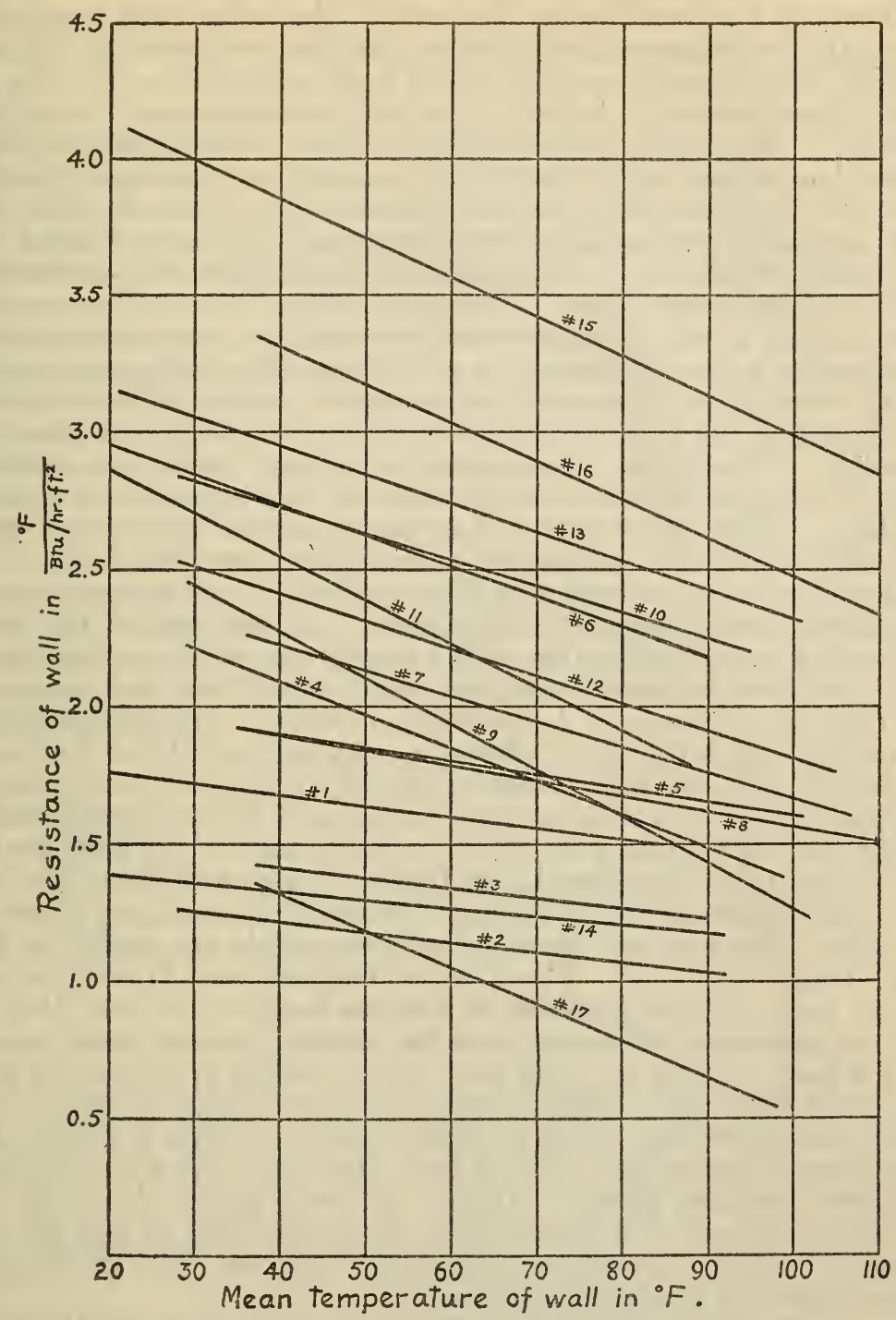

FIGURE 13.-Resistance of walls for various mean temperatures

No. 1, 8-inch brick (Baltimore).

No. 2, 8-inch brick (New England).

No. 3, 8-inch brick (Mississippi).

No. 4, 12-inch brick.

No. 5, 8-inch brick; furrowed horizontal joints; unfilled vertical longitudinal joints.

No. 6, 8-inch furred brick.

No. 7, 8-ineh rolokbak.

No. 8, 8-inch all rolok.

No. 9, 8-inch all rolok.

No. 10, 8-inch hollow tile (end construction).

No. 11, 8-inch hollow tile (side construction).

No. 12, 8-inch hollow tile (double shell).

No. 13, 8-inch hollow tile (two unit).

No. 14, 8-inch Portland cement block.

No. 15, 4-inch frame (furred).

No. 16, 4-inch frame (without stueco and furring).

No. 17, air space. 
the theory of heat conduction that even if the entire edge were maintained at the temperature of either the hot or the cold side, the resulting error would be only of the order of 10 per cent. In the present measurements the edges are well insulated and the error is necessarily very much less than this. These conclusions have been reached by considering temperature measurements made on the edges of panels, together with calculations made by Peirce. ${ }^{6}$ The edge effect increases very rapidly with increasing thickness of panel and may be appreciable in the case of the 13 -inch brick wall, accounting for the rather steep slope. The magnitudes, however, are not significant in the range of temperature covered, but extrapolation of the experimental values is hazardous and obviously wholly unnecessary.

Walls containing air spaces present much greater difficulties, since calculations of the effects of lateral heat flow are subject to great uncertainty. Theoretical considerations indicate that the observed slopes of the resistance curves for walls of this type are, in general, too steep. These effects are not great enough to have any particular significance in the estimation of heat loss from buildings. They are, however, very annoying in the consideration of the accuracy of the observations presented in this paper. In the case of the frame wall, a very rough estimation of the magnitude of lateral heat transfer by radiation indicated that this effect should not produce significant error in the range of temperature covered. The uncertainty in this calculation, however, is admitted. Experimental test was made by placing thin vertical radiation shields in the air space, but no significant effect on the measured resistance of the wall was noted.

The eflect of vertical convection in frame and in end construction tile remains to be considered. In these types of wall there is a path for air circulation up the hot side to the top of the wall and down the cold side. The tops and bottoms of such panels are sealed, so that no air leaks in or out. The work of Griffiths and Davis ${ }^{7}$ on convection from vertical surfaces of various heights indicates that for small temperature differences and for heights greater than about 2 feet the heat transfer per unit area by convection is practically independent of the hejght. This means that the air rising along a warmer surface (or descending along a colder surface) reaches a steady state after about 2 feet of rise (or fall) from the place where it first comes in contact with the surface. It does not seem likely, therefore, that the small amount of heat exchange to the outside at the top and bottom of the test panels will influence the heat flow through the central region to any significant extent.

Another possible source of error is present in the case of the frame walls tested, which would not tend to cause too steep a slope of the resistance curve, but would be in the same direction throughout the range of temperature covered. 'The test panel has a central vertical stud, which offers a path of considerably greater resistance to heat flow than the same area of air space. There is a possibility that the temperature distribution over the plaster surface would be sufficiently nonuniform to cause significant error in the conductimeter readings. To determine whether such an effect is appreciable, a flat copper plate, 1 foot square and one-sixteenth inch thick was cemented on the plaster surface immediately over the area covered by the conducti- 
meter. On account of the high thermal conductivity of copper, any lateral temperature gradients in the plaster surface would be greatly reduced. Observations made under these conditions showed no systematic change in the measured resistance of the panel.

The cause of the observed steepness in the resistance curves of certain walls still remains obscure, but it is probable that the effects are bound up in some way with the departure of the mean temperature of the wall specinen from the temperature of the test room. It is worthy of note that Rowley and his associates, ${ }^{8}$ working with walls containing air spaces, observed these effects to a much greater degree. Other experimenters in this field have paid little or no attention to the variation of resistance with temperature. The existence of other sources of error might be mentioned, such as slow absorption or evaporation of moisture during test; conceivably producing a false, steady state, or peculiar effects of convection in the air spaces. It will be observed that all these hypothetical effects are intimately connected with the departure of the mean temperature of the wall from testroom temperature. Their magnitude and even their direction, however, is problematical. Extensive investigation with elaborate apparatus could no doubt clear up these discrepancies, but in view of the uncertain nature of the individual wall such refinements would appear to be superfluous.

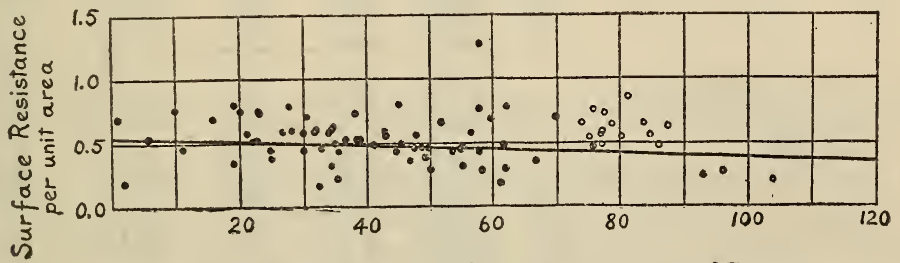

Mean temperature of air and surface in ${ }^{\circ} \mathrm{F}$.

FIGURE 14.-Surface resistances for different mean temperatures

It may be concluded, however, that the magnitude of the discrepancies discussed above are not great enough to have any particular significance in the estimation of heat losses through building walls in the range of temperature they experience under ordinary conditions.

Little significant information was gained from the data on temperature distribution in the interior of the walls. The indications are, however, that the isothermal surfaces are practically plane over the central region, but due to the nonuniform nature of the walls, and the difficulty in precise location of the thermocouples, the observations have no great significance.

The data on surface resistance obtained in these experiments are shown in Table 3 and Figure 14. The precision of these data is limited, since the temperature differences between the air and the surfaces were rather small. In any case, however, the results apply only to the particular conditions existing in the apparatus. The abscissa in Figure 14 is the mean of the temperature of the surface and that of the air, the latter being measured by a couple about 3 inches from the surface. The ordinate is the resistance per unit area in ${ }^{\circ} \mathrm{F}$ for a heat flow of $1 \mathrm{~B}$. t. $\mathrm{u}$. per hour per square foot between the air and surface. 
As already noted, it was necessary to create considerable air motion in order to maintain a uniform temperature distribution over the test panel, and the results apply for this air velocity (about 5 miles per hour) and not for natural convection. They represent, perhaps, a rough average between usual inside and outside conditions. If two such surface resistances be added to the resistance of a wall, the sum will represent the total resistance of a wall under average conditions as nearly as it is possible to define them.

TABLt 3

\begin{tabular}{|c|c|c|c|c|c|c|c|}
\hline Wall & Description & $\begin{array}{l}\text { Temper- } \\
\text { ature of } \\
\text { cold } \\
\text { surface }\end{array}$ & $\begin{array}{l}\text { Temper- } \\
\text { ature of } \\
\text { cold air }\end{array}$ & $\Delta t$ & $\begin{array}{l}\text { Heat } \\
\text { flow }\end{array}$ & $\begin{array}{l}\text { Surface } \\
\text { resist- } \\
\text { ance }\end{array}$ & $\begin{array}{l}\text { Mean } \\
\text { tempera- } \\
\text { ture of } \\
\text { surface }\end{array}$ \\
\hline No. 1.- & 8-inch brick (Baltimore) & $\begin{array}{l}\circ F . \\
10.1 \\
52.0 \\
37.6 \\
26.8\end{array}$ & $\begin{array}{r}{ }^{\circ} F_{1} \\
1.3 \\
42.7 \\
28.1 \\
15.5\end{array}$ & $\begin{array}{r}\circ F . \\
8.8 \\
9.3 \\
5.5 \\
11.3\end{array}$ & $\begin{array}{r}\text { B. t. u. } \\
h r .-1 \text { ft. } \\
\text { it } \\
20.6 \\
20.3 \\
19.5 \\
19.8\end{array}$ & $\begin{array}{r}0.53 \\
.46 \\
.46 \\
.57\end{array}$ & $\begin{array}{r}{ }^{\circ} F . \\
5.7 \\
47.4 \\
32.8 \\
21.2\end{array}$ \\
\hline \multirow[t]{2}{*}{ No. 2... } & 8-inch brick (New England) & $\begin{array}{l}32.4 \\
24.9 \\
52.4 \\
65.8\end{array}$ & $\begin{array}{l}21.2 \\
15.3 \\
37.9 \\
49.7\end{array}$ & $\begin{array}{r}11.2 \\
9.6 \\
14.5 \\
16.1\end{array}$ & $\begin{array}{l}19.1 \\
13.2 \\
18.3 \\
21.4\end{array}$ & $\begin{array}{l}.59 \\
.73 \\
.79 \\
.75\end{array}$ & $\begin{array}{l}26.8 \\
20.1 \\
45.2 \\
57.8\end{array}$ \\
\hline & & $\begin{array}{l}35.2 \\
28.4 \\
53.3 \\
49.8\end{array}$ & $\begin{array}{l}21.4 \\
15.9 \\
37.7 \\
32.4\end{array}$ & $\begin{array}{l}13.8 \\
12.5 \\
15.6 \\
17.4\end{array}$ & $\begin{array}{l}22.8 \\
24.6 \\
31.0 \\
35.2\end{array}$ & $\begin{array}{l}.60 \\
.51 \\
.50 \\
.49\end{array}$ & $\begin{array}{l}28.3 \\
22.2 \\
45.5 \\
41.1\end{array}$ \\
\hline No.3..- & 8-inch brick (Mississippi) & $\begin{array}{l}51.3 \\
37.4\end{array}$ & $\begin{array}{l}34.2 \\
23.7\end{array}$ & $\begin{array}{l}17.1 \\
13.7\end{array}$ & $\begin{array}{l}29.4 \\
19.6\end{array}$ & $\begin{array}{l}.58 \\
.70\end{array}$ & $\begin{array}{l}42.8 \\
30.6\end{array}$ \\
\hline No. 4 -.- & 12-inch brick........ & $\begin{array}{l}33.8 \\
54.6 \\
29.2\end{array}$ & $\begin{array}{l}21.9 \\
42.4 \\
17.2\end{array}$ & $\begin{array}{l}11.9 \\
12.2 \\
12.0\end{array}$ & $\begin{array}{l}15.4 \\
26.7 \\
15.9\end{array}$ & $\begin{array}{l}.77 \\
.46 \\
.75\end{array}$ & $\begin{array}{l}27.8 \\
48.5 \\
23.2\end{array}$ \\
\hline No. $5 \ldots$ & 8-inch brick.......... & $\begin{array}{l}58.8 \\
35.2\end{array}$ & $\begin{array}{l}48.1 \\
24.7\end{array}$ & $\begin{array}{l}10.7 \\
10.5\end{array}$ & $\begin{array}{l}25.2 \\
18.1\end{array}$ & $\begin{array}{l}.42 \\
.58\end{array}$ & $\begin{array}{l}53.4 \\
30.0\end{array}$ \\
\hline No.6.-- & 8-inch furred brick.... & $\begin{array}{r}43.9 \\
15.1 \\
5.9 \\
52.0\end{array}$ & $\begin{array}{r}34.1 \\
5.0 \\
-4.4 \\
43.5\end{array}$ & $\begin{array}{r}9.8 \\
10.1 \\
10.3 \\
8.5\end{array}$ & $\begin{array}{l}18.9 \\
13.5 \\
14.9 \\
15.2\end{array}$ & $\begin{array}{l}.52 \\
.75 \\
.69 \\
.56\end{array}$ & $\begin{array}{r}39.0 \\
10.0 \\
0.8 \\
47.8\end{array}$ \\
\hline No. $7 \ldots$ & 8-inch rolokbak............... & $\begin{array}{l}61.0 \\
36.4 \\
38.8\end{array}$ & $\begin{array}{l}49.1 \\
27.4 \\
31.3\end{array}$ & $\begin{array}{r}11.9 \\
9.0 \\
7.5\end{array}$ & $\begin{array}{l}25.1 \\
15.2 \\
15.0\end{array}$ & $\begin{array}{l}.47 \\
.59 \\
.50\end{array}$ & $\begin{array}{l}55.0 \\
31.9 \\
35.0\end{array}$ \\
\hline Yo. 8 & 8-inch all rolok & $\begin{array}{l}64.3 \\
36.2 \\
42.6\end{array}$ & $\begin{array}{l}51.2 \\
25.7 \\
34.0\end{array}$ & $\begin{array}{r}13.1 \\
10.5 \\
8.6\end{array}$ & $\begin{array}{l}31.6 \\
17.5 \\
16.5\end{array}$ & $\begin{array}{l}.41 \\
.60 \\
.52\end{array}$ & $\begin{array}{l}57.8 \\
32.0 \\
38.3\end{array}$ \\
\hline No.9... & 8-inch all rolok & $\begin{array}{l}58.5 \\
39.9 \\
38.9 \\
61.3 \\
65.4\end{array}$ & $\begin{array}{l}51.4 \\
33.1 \\
30.7 \\
55.1 \\
58.7\end{array}$ & $\begin{array}{l}7.1 \\
6.8 \\
8.2 \\
6.2 \\
6.7\end{array}$ & $\begin{array}{l}22.8 \\
13.2 \\
13.5 \\
22.8 \\
23.3\end{array}$ & $\begin{array}{l}.31 \\
.52 \\
.61 \\
.27 \\
.29\end{array}$ & $\begin{array}{l}55.0 \\
36.5 \\
34.8 \\
58.2 \\
62.0\end{array}$ \\
\hline No. 10. & $\begin{array}{l}\text { 8-inch hollow tile (end construc- } \\
\text { tion). }\end{array}$ & $\begin{array}{l}14.2 \\
27.9 \\
52.8\end{array}$ & $\begin{array}{r}8.1 \\
22.3 \\
46.1\end{array}$ & $\begin{array}{l}6.1 \\
5.6 \\
6.7\end{array}$ & $\begin{array}{l}13.4 \\
15.0 \\
17.4\end{array}$ & $\begin{array}{l}.46 \\
.37 \\
.38\end{array}$ & $\begin{array}{l}11.2 \\
25.1 \\
49.4\end{array}$ \\
\hline No. 11. & $\begin{array}{l}\text { 8-inch hollow tile (side construc- } \\
\text { tion). }\end{array}$ & $\begin{array}{l}20.5 \\
38.7 \\
38.5 \\
48.4\end{array}$ & $\begin{array}{l}11.6 \\
31.8 \\
32.2 \\
40.6\end{array}$ & $\begin{array}{l}8.9 \\
6.9 \\
6.3 \\
7.8\end{array}$ & $\begin{array}{l}13.0 \\
15.8 \\
15.1 \\
18.8\end{array}$ & $\begin{array}{l}.68 \\
.44 \\
.42 \\
.42\end{array}$ & $\begin{array}{l}16.0 \\
30.2 \\
35.4 \\
44.5\end{array}$ \\
\hline No. 12. & 8-inch hollow tile (double shell) .. & $\begin{array}{l}27.8 \\
49.0 \\
69.6\end{array}$ & $\begin{array}{l}22.0 \\
44.2 \\
63.4\end{array}$ & $\begin{array}{l}5.8 \\
4.8 \\
6.2\end{array}$ & $\begin{array}{l}12.9 \\
13.4 \\
17.8\end{array}$ & $\begin{array}{l}.45 \\
.36 \\
.35\end{array}$ & $\begin{array}{l}24.9 \\
46.6 \\
66.5\end{array}$ \\
\hline No. 13.. & 8-inch hollow tile (tro unit) ..... & $\begin{array}{l}21.4 \\
36.7 \\
52.7\end{array}$ & $\begin{array}{l}17.2 \\
32.0 \\
47.3\end{array}$ & $\begin{array}{l}4.2 \\
4.7 \\
5.4\end{array}$ & $\begin{array}{l}12.9 \\
15.4 \\
18.9\end{array}$ & $\begin{array}{l}.33 \\
.31 \\
.29\end{array}$ & $\begin{array}{l}19.3 \\
34.4 \\
50.0\end{array}$ \\
\hline
\end{tabular}


TABLE 3.-Continued

\begin{tabular}{|c|c|c|c|c|c|c|}
\hline Description & $\begin{array}{l}\text { Temper- } \\
\text { ature of } \\
\text { cold } \\
\text { surface }\end{array}$ & $\begin{array}{l}\text { Temper- } \\
\text { ature of } \\
\text { cold air }\end{array}$ & $\Delta t$ & $\begin{array}{l}\text { Heat } \\
\text { low }\end{array}$ & $\begin{array}{l}\text { Surface } \\
\text { resist- } \\
\text { ance }\end{array}$ & $\begin{array}{c}\text { Mean } \\
\text { tempera- } \\
\text { ture of } \\
\text { 'surface }\end{array}$ \\
\hline No.14_. 8-inch cement block.. & $\begin{array}{r}\circ F . \\
38.1 \\
34.4 \\
3.8 \\
63.2\end{array}$ & $\begin{array}{r}\circ F . \\
32.9 \\
30.2 \\
59.3 \\
59.6\end{array}$ & $\begin{array}{r}{ }^{\circ} F . \\
5.2 \\
4.2 \\
3.5 \\
3.6\end{array}$ & $\begin{array}{r}\text { B.t. } u . . \\
h r_{0}^{-1}-\mathbf{f t} .-2 \\
24.7 \\
25.6 \\
18.3 \\
20.6\end{array}$ & $\begin{array}{r}0.21 \\
.16 \\
.19 \\
.17\end{array}$ & $\begin{array}{r}{ }^{\circ} F \\
35.5 \\
32.3 \\
2.0 \\
61.4\end{array}$ \\
\hline \multirow[t]{3}{*}{ No. 15.. 4-inch frame (furred) } & $\begin{array}{l}72.6 \\
62.9 \\
54.7 \\
25.0\end{array}$ & $\begin{array}{l}66.9 \\
56.6 \\
49.0 \\
20.5\end{array}$ & $\begin{array}{l}5.7 \\
6.3 \\
5.7 \\
4.5\end{array}$ & $\begin{array}{l}8.3 \\
9.4 \\
8.7 \\
8.7\end{array}$ & $\begin{array}{l}.69 \\
.67 \\
.65 \\
.52\end{array}$ & $\begin{array}{l}69.8 \\
59.8 \\
51.8 \\
22.8\end{array}$ \\
\hline & $\begin{array}{l}66.5 \\
4.5 \\
63.1 \\
26.2\end{array}$ & $\begin{array}{l}58.8 \\
40.3 \\
52.7 \\
20.4\end{array}$ & $\begin{array}{r}7.7 \\
5.3 \\
10.4 \\
5.8\end{array}$ & $\begin{array}{r}10.0 \\
9.6 \\
8.2 \\
7.9\end{array}$ & $\begin{array}{r}.77 \\
.55 \\
1.27 \\
.73\end{array}$ & $\begin{array}{l}62.6 \\
43.0 \\
57.9 \\
23.3\end{array}$ \\
\hline & $\begin{array}{l}62.2 \\
22.5 \\
94.0 \\
97.3\end{array}$ & $\begin{array}{l}47.1 \\
15.7 \\
92.0 \\
95.0\end{array}$ & $\begin{array}{l}5.1 \\
6.8 \\
2.0 \\
2.3\end{array}$ & $\begin{array}{r}11.4 \\
8.6 \\
8.8 \\
8.7\end{array}$ & $\begin{array}{l}.45 \\
.79 \\
.23 \\
.26\end{array}$ & $\begin{array}{l}54.6 \\
19.1 \\
93.0 \\
96.2\end{array}$ \\
\hline No. 16_. 4-inch frame....... & $\begin{array}{l}79.1 \\
41.2 \\
59.0 \\
36.9\end{array}$ & $\begin{array}{l}72.3 \\
35.0 \\
53.9 \\
31.7\end{array}$ & $\begin{array}{l}6.8 \\
6.2 \\
5.1 \\
5.2\end{array}$ & $\begin{array}{r}14.9 \\
8.6 \\
8.9 \\
8.6\end{array}$ & $\begin{array}{l}.46 \\
.72 \\
.57 \\
.60\end{array}$ & $\begin{array}{l}75.7 \\
38.1 \\
56.4 \\
34.3\end{array}$ \\
\hline No.17_._ Air space............. & $\begin{array}{l}66.6 \\
37.3 \\
52.7\end{array}$ & $\begin{array}{l}56.8 \\
30.6 \\
46.6\end{array}$ & $\begin{array}{l}9.8 \\
6.7 \\
6.1\end{array}$ & $\begin{array}{l}20.6 \\
11.6 \\
13.2\end{array}$ & $\begin{array}{r}.48 \\
.88 \\
.16\end{array}$ & $\begin{array}{l}61.7 \\
34.0 \\
49.6\end{array}$ \\
\hline
\end{tabular}

\section{TESTS ON SMALL PANELS BY HOT-PLATE METHOD}

A series of tests was made on small panels, each of which is a component of frame wall construction. The apparatus used in these tests is different from that described above for the large walls. It consists of a flat electric heater built with an edge heater according to the usual designs of a hot plate for thermal conductivity apparatus outside total dimensions being 24 inches square. The panels tested ${ }^{9}$ were 32 by 32 inches in total area, two specimens of each type being used in each test. Thermocouples were pasted on both surfaces of each panel, as well as on the surfaces of the hot plate. One specimen was placed on each side of the heater and the whole combination was clamped together. Considerable insulation was wrapped around the edge. Thermometers were hung in the air, about 4 inches from the surface of each panel. In each case the sheathing was placed against the hot plate.

The results of these tests are given in Table 4 and Figure 15. The data on surface resistance per unit area given in columns 10 and 11 is plotted with the previous data in Figure 14. It will be noted that the group of points in Figure 14 (those represented by circles) which give the surface resistances obtained by this second method, are higher than the average indicated by the previous points. This is explained by the difference in the air velocities along the surfaces in the two cases. In the latter experiments there were no forced convection, but merely that which would arise through a temperature difference between the surface and the air in the vicinity. 
TABLE 4.-Observations made with hot plate 24 inches square

\begin{tabular}{|c|c|c|c|c|c|c|c|c|c|c|c|}
\hline$\stackrel{\bar{\varpi}}{\bar{\xi}}$ & Description & 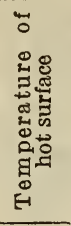 & 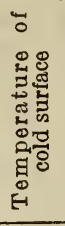 & 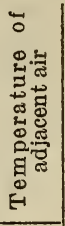 & 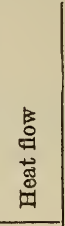 & 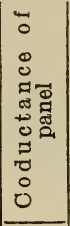 & 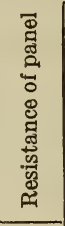 & 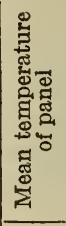 & 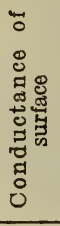 & 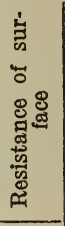 & 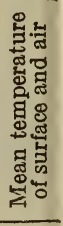 \\
\hline No. 18.. & 3/4-inch sheathing, paper.... & $\begin{array}{l}\circ F . \\
152.2 \\
128.4 \\
102.4\end{array}$ & $\begin{aligned} & \circ F \\
& 100.9 \\
& 92.9 \\
& 82.9\end{aligned}$ & $\begin{array}{l}\circ F . \\
73.8 \\
74.2 \\
72.0\end{array}$ & $\begin{array}{c}\text { B.t.u. } \\
\text { hr. }-1 \\
\text { ft.- } \\
43.0 \\
29.2 \\
15.1\end{array}$ & $\begin{array}{c}\text { B.t.u. } \\
\text { hr. } \\
\text { ft.-2 } \\
\text { deg. } \\
\text { F. } \\
0.84 \\
.82 \\
.78\end{array}$ & $\begin{array}{l}\text { 1. } 19 \\
\text { 1. } 22 \\
1.29\end{array}$ & $\begin{array}{r}126.6 \\
110.7 \\
92.7\end{array}$ & $\begin{array}{l}1.59 \\
1.56 \\
1.39\end{array}$ & $\begin{array}{r}0.63 \\
.64 \\
.72\end{array}$ & $\begin{array}{l}87.4 \\
83.6 \\
77.4\end{array}$ \\
\hline No. 19_- & $\begin{array}{l}\text { 3/4-inch sheathing, paper, } \\
\text { shingles. }\end{array}$ & $\begin{array}{l}129.8 \\
101.6\end{array}$ & $\begin{array}{l}84.4 \\
78.8\end{array}$ & $\begin{array}{l}73.2 \\
72.3\end{array}$ & $\begin{array}{r}17.9 \\
8.7\end{array}$ & .395 & $\begin{array}{l}2.53 \\
2.61\end{array}$ & $\begin{array}{r}107.1 \\
90.2\end{array}$ & $\begin{array}{l}1.60 \\
1.34\end{array}$ & $\begin{array}{l}.63 \\
.75\end{array}$ & \\
\hline No. 20 & $\begin{array}{l}\text { 3/4-inch sheathing, paper, } \\
\text { clapboards. }\end{array}$ & $\begin{array}{l}102.0 \\
157.3\end{array}$ & $\begin{array}{l}\text { 79. } 9 \\
93.2\end{array}$ & $\begin{array}{l}74.4 \\
75.9\end{array}$ & $\begin{array}{r}9.5 \\
31.7\end{array}$ & $\begin{array}{l}.43 \\
.49\end{array}$ & $\begin{array}{l}2.32 \\
2.03\end{array}$ & $\begin{array}{r}91.0 \\
125.2\end{array}$ & $\begin{array}{l}1.73 \\
1.83\end{array}$ & $\begin{array}{l}.58 \\
.55\end{array}$ & \\
\hline No. 21_. & $\begin{array}{l}\text { 3/1-inch sheathing, paper, } \\
\text { clapboards,paper,shingles. }\end{array}$ & $\begin{array}{r}135.5 \\
95.0 \\
144.9 \\
142.4 \\
99.8\end{array}$ & $\begin{array}{l}84.3 \\
75.1 \\
87.8 \\
81.2 \\
76.9\end{array}$ & $\begin{array}{l}76.6 \\
72.0 \\
74.6 \\
72.5 \\
73.7\end{array}$ & $\begin{array}{r}14.3 \\
4.8 \\
15.7 \\
15.5 \\
5.1\end{array}$ & $\begin{array}{l}.28 \\
.24 \\
.27 \\
.25 \\
.22\end{array}$ & $\begin{array}{l}3.58 \\
4.18 \\
3.64 \\
3.96 \\
4.49\end{array}$ & $\begin{array}{r}109.9 \\
85.1 \\
116.3 \\
111.8 \\
88.3\end{array}$ & $\begin{array}{l}1.86 \\
1.55 \\
1.19 \\
1.78 \\
1.59\end{array}$ & $\begin{array}{l}.54 \\
.65 \\
.84 \\
.56 \\
.63\end{array}$ & $\begin{array}{l}80.4 \\
73.6 \\
81.2 \\
76.8 \\
75.3\end{array}$ \\
\hline No. 22 & $\begin{array}{l}\text { 3/-inch sheathing, paper, } \\
\text { 3/1-inch furring air space, } \\
\text { metal lath, stucco. }\end{array}$ & $\begin{array}{r}89.1 \\
156.1\end{array}$ & $\begin{array}{l}78.5 \\
93.9\end{array}$ & $\begin{array}{l}76.0 \\
78.0\end{array}$ & $\begin{array}{r}5.1 \\
33.3\end{array}$ & $\begin{array}{l}.48 \\
.535\end{array}$ & $\begin{array}{l}\text { 2. } 07 \\
1.87\end{array}$ & $\begin{array}{r}83.8 \\
125.0\end{array}$ & $\begin{array}{l}2.04 \\
2.09\end{array}$ & $\begin{array}{l}.49 \\
.48\end{array}$ & $\begin{array}{l}77.2 \\
86.0\end{array}$ \\
\hline
\end{tabular}

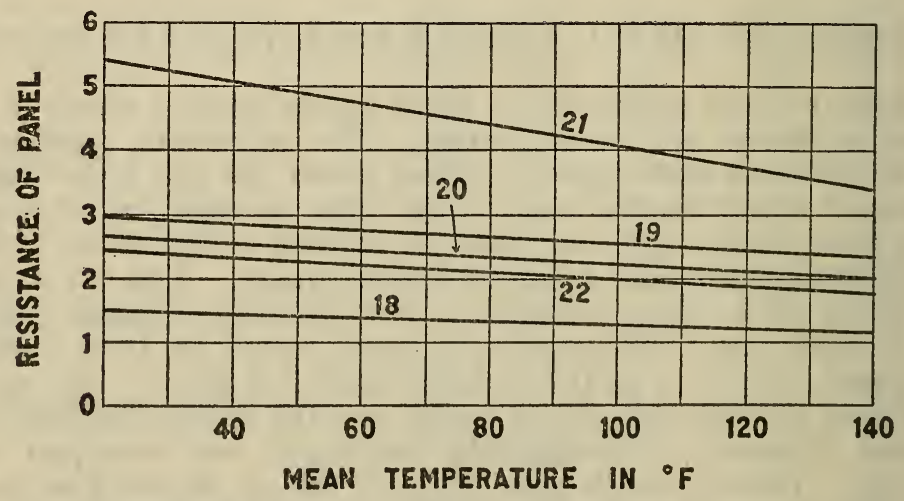

FIGURE 15.-Resistances of panels tested with 24 by 24 inch hot plate

\section{CALCULATION OF THE CONDUCTANCE, RESISTANCE, AND TRANSMITTANCE OF WALLS AND THEIR COMPO- NENT PARTS}

In order to make data on the heat transmission through walls of basic value in the design and study of building structures, it is not only necessary to know what the values are for any particular construction, but it is essential to be able to calculate beforehand what the values might be for any desired combination of materials. To conduct tests on all possible combinations is entirely impracticable. It is possible, however, to utilize the ordinary simple laws of heat flow and, with a knowledge of the values for a relatively few basic constituents, to compute the conductance, resistance, and transmit- 
tance per unit area of any combination of these components with reasonable accuracy. In this section an analysis is made of the data on the complete walls, and values are obtained for the various components as well as for a number of walls which have not been tested.

It should be noted that certain components that are cited in Table 5 are somewhat hypothetical. For example, in considering the resistance of the furring air space, what is meant is the resistance of that given width of space set off by furring strips, where the two surfaces are inclosed, either by paper, sheathing, or any other solid material, but does not include spaces open on one side.

TABLE 5.-Values for walls and component parts at a mean temperature of $50^{\circ} \mathrm{F}$.

[Values of resistance $R$, conductance $C$, and transmittance $T$ based on a value of surface resistance equa] to 1.0. The following are values taken from the curves of Figures 13 and 15]

\begin{tabular}{|c|c|c|c|c|}
\hline Item & Description & $R$ & $C$ & $T=\frac{1}{1+R}$ \\
\hline $\begin{array}{l}1 \\
2 \\
3 \\
4\end{array}$ & $\begin{array}{l}\text { 8-inch brick, } 3 / 4 \text {-inch plaster (average of wails Nos. } 1,2 \text {, and 3) } \\
\text { 8-inch brick, } 7 / 8 \text {-inch furring (inside), 3/4-inch plaster (wall No. 6) } \\
\text { 8-inch hollow tile, end construction, plaster, stucco (wall No. 10) } \\
\text { 8-inch hollow tile, side construction, plaster, stucco (wall No. 11) }\end{array}$ & $\begin{array}{l}\text { 1. } 37 \\
\text { 2. } 61 \\
2.63 \\
2.39\end{array}$ & $\begin{array}{r}0.73 \\
.38 \\
.38 \\
.42\end{array}$ & $\begin{array}{l}0.42 \\
.28 \\
.28 \\
.295\end{array}$ \\
\hline $\begin{array}{l}5 \\
6 \\
7 \\
8\end{array}$ & $\begin{array}{l}\text { 8-inch hollow tile, end construction, plaster only (wall No. 12) } \\
\text { 8-inch hollow tile, end construction, plaster, stucco (wall No. 13) } \\
\text { 8-inch hollow cement block, } 3 / 4 \text {-inch plaster (wall No. 14) } \\
\text { Frame: wood lath and plaster, } 2 \text { by } 4 \text { studs, sheathing, paper, } 7 / 8 \text {-inch } \\
\text { furring (outside), metal lath and stucco (wall No. 15) }\end{array}$ & $\begin{array}{l}2.31 \\
2.84 \\
1.30 \\
4.11\end{array}$ & $\begin{array}{l}.43 \\
.35 \\
.77 \\
.24\end{array}$ & $\begin{array}{l}.30 \\
.26 \\
.435 \\
.20\end{array}$ \\
\hline $\begin{array}{r}9 \\
10 \\
11 \\
12\end{array}$ & $\begin{array}{l}\text { Same as } 8 \text {, less furring (outside), metal lath and stucco (wall No. 16) } \\
\text { 8-inch rolokbak, } 3 / 4 \text {-inch plaster (wall No. } 7 \text { ) } \\
\text { 8-inch all-rolok, } 3 / 4 \text {-inch plaster (average of walls Nos. } 8 \text { and } 9 \text { ) } \\
3 / 4 \text {-inch sheathing, paper (wall No. 18) }\end{array}$ & $\begin{array}{l}3.43 \\
2.14 \\
1.98 \\
1.40\end{array}$ & $\begin{array}{l}.29 \\
.47 \\
.505 \\
.71\end{array}$ & $\begin{array}{l}.23 \\
.32 \\
.34 \\
.42\end{array}$ \\
\hline $\begin{array}{l}13 \\
14 \\
15 \\
16\end{array}$ & $\begin{array}{l}3 / 4 \text {-inch sheathing, paper, shingles (wall No. 19) } \\
3 / 4 \text {-inch sheathing, paper, clapboards (wall No. 20) } \\
3 / 4 \text {-inch sheathing, paper, clapboards, paper, shingles (wail No. } 21 \text { ) } \\
3 / 4 \text {-inch sheathing, paper, } 3 / 4 \text {-inch furring, metal lath and stucco (wall } \\
\text { No. 22) }\end{array}$ & $\begin{array}{l}\text { 2. } 81 \\
\text { 4. } 50 \\
\text { 2. } 26\end{array}$ & $\begin{array}{r}.36 \\
.40 \\
.20 \\
.44\end{array}$ & $\begin{array}{r}.26 \\
.29 \\
.17 \\
.31\end{array}$ \\
\hline
\end{tabular}

In Table 5 the values have been taken from the curves of Figure 13, and correspond to a mean temperature of $50^{\circ} \mathrm{F}$. $C$ is the conductance in B. t. u. per hour per square foot per ${ }^{\circ} \mathrm{F}$. temperature difference between the surfaces of the wall. $R$ is the resistance, and is numerically equal to $1 / C$.

In all these calculations the total resistance of the two surfaces of a wall is taken as equal to $1^{\circ} \mathrm{F}$. per unit heat flow $(1 \mathrm{~B}$. t. u. per hour per square foot). This is believed to be a reasonably good average value for ordinary temperatures and air velocities. The resistance of a wall figured from air to air will then be 1 plus the resistance from surface to surface. $T$ is the transmittance and is defined numerically as being equal to $1 /(1+R)$.

In computing the values given in Table 6 , the following additional values have been used, where $k$ is the thermal conductivity in B. t. u. per hour per square foot per ${ }^{\circ} \mathrm{F}$. per inch.

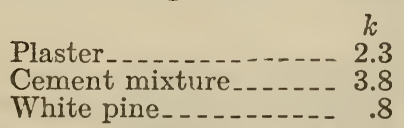

In calculating the value for wood lath and plaster, the dimensions for the lath were taken as $13 / 8$ by $5 / 6$ inch, and spaced apart one-fourthinch. The value for wood lath and plaster given in the table was calcula- 
ted on the basis that plaster was keyed into the spacings between the lath to a depth of five-sixteenths inch, and in addition for a thickness of three-fourths inch from the surface of the lath.

\section{TABLE 6.-Derived data for use in calculations}

[The following values are based on estimated values of the thermal conductivity of each material concerned]

\begin{tabular}{|c|c|c|c|}
\hline Item & Description & $R$ & $C$ \\
\hline $\begin{array}{l}17 \\
18 \\
19\end{array}$ & $\begin{array}{l}\text { 3/4-inch plaster (with or without metal lath) } \\
3 / 4 \text {-inch stucen } \\
\text { Wood lath, } 3 / 4 \text {-inch plaster }\end{array}$ & $\begin{array}{r}0.33 \\
.20 \\
.63\end{array}$ & $\begin{array}{l}\text { 3. } 03 \\
5.00 \\
1.59\end{array}$ \\
\hline
\end{tabular}

[The following values are derived from the data on walls nos. 1 and 6 , fig. 13, taking into account the mean temperature of the furring air space for different mean temperatures of the entire wall No. 6.]

\begin{tabular}{|c|c|c|c|}
\hline Item & Description & $R$ & $C$ \\
\hline 20 & 78-inch furring air space, $55^{\circ}$ to $60^{\circ} \mathrm{F}$. mean temperature; to be referred to as & \multirow{2}{*}{$\begin{array}{l}0.96 \\
1.10\end{array}$} & \multirow{2}{*}{$\begin{array}{l}1.04 \\
0.91\end{array}$} \\
\hline 21 & $\begin{array}{l}\text { 7\&-inch furring air space, } 35^{\circ} \text { to } 40^{\circ} \mathrm{F} \text {. mean temperature; to be referred to as "out- } \\
\text { side iurring" }\end{array}$ & & \\
\hline
\end{tabular}

[The following values for components and complete walls are based on all of above values, derived as indicated]

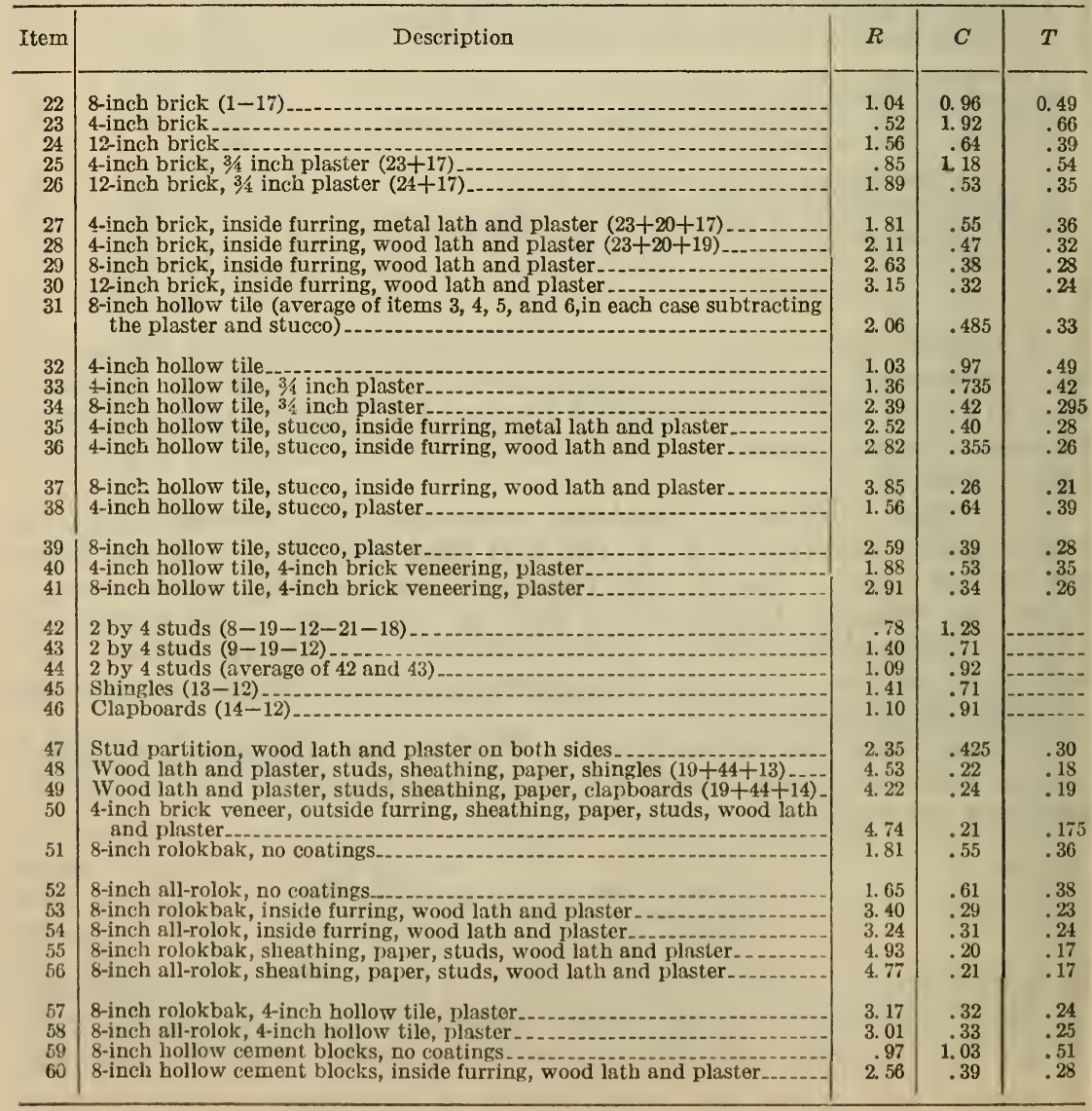




\section{REVIEW AND COMPARISON OF DATA BY PREVIOUS EXPERIMENTERS}

Many of the data of previous experimenters have been omitted here because they relate to structures much different from those examined in this paper. In the work of Bugge ${ }^{10}$ the values obtained on various structures are compared with one type selected as a standard; and since no absolute values for conductance are given, the data have not been considered here.

In the following, comparisons are made by adding the resistances of each component of the wall structure as described by the particular experiments, using the values of Tables 5 and 6 above. The total resistance thus obtained is compared with the total resistance (from surface to surface) computed directly from the data in each individual paper. In computing these resistances, wherever necessary and possible, the values of the surface resistances have been taken directly or calculated from data given in that particular paper. If no data are given in the papers the value for the resistance of the two external surfaces has been taken equal to 1.0 .

Data by L. M. Arkley (Bulletin No. 1, 1919, School of Engineering Research, University of Toronto, $p p .115-129)$

TESTS MADE IN 1912

\begin{tabular}{|c|c|c|c|}
\hline \multirow{2}{*}{$\begin{array}{l}\text { Test } \\
\text { No. }\end{array}$} & \multirow[b]{2}{*}{ Description } & \multicolumn{2}{|c|}{$R$} \\
\hline & & $\begin{array}{l}\text { Calcul- } \\
\text { lated }\end{array}$ & Arkley \\
\hline $\begin{array}{l}1 \\
4\end{array}$ & 8-inch hollow concrete block wail, not plastered; air spaces empty & 0.97 & \\
\hline$\frac{4}{7}$ & $\begin{array}{l}\text { 8-inch hollow concrete block wall, air spaces empty, plaster on both sides } \\
\text { 8-inch hollow concrete block wall, air spaces empty; plaster on both sides; } 1\end{array}$ & 1.63 & \\
\hline . & $\begin{array}{l}\text { layer of tarred building paper on high temperature side of wall } \\
\text { 8-inch hollow concrete block wall, air spaces empty; plaster on both sides; } 1\end{array}$ & 1.63 & \\
\hline & layer of asphalt paper on high temperature side of wall & 1.63 & \\
\hline $\begin{array}{r}9 \\
10\end{array}$ & 9-inch brick wall, without plaster & 1. 17 & \\
\hline 11 & $7 \%$-inch hollow tile; air spaces empty; no plaster... & 2. 00 & 1.40 \\
\hline
\end{tabular}

\section{TESTS MADE IN 1913}

\begin{tabular}{|c|c|c|c|}
\hline 1 & 12-inch tile wall, laid with hollow spaces horizontal & 3.09 & 2.39 \\
\hline 2 & $\begin{array}{l}\text { Same as of test No. 1, but with } 1 \text { layer of paper on high temperature side of } \\
\text { wall }\end{array}$ & 3.09 & 3.76 \\
\hline 3 & $\begin{array}{l}\text { Same as of test No. } 1 \text {, with } 1 \text { coat of dehydratine painted on high temperature } \\
\text { side of wall }\end{array}$ & 3.09 & 3.85 \\
\hline 4 & $\begin{array}{l}\text { 12-inch tile wall, laid with hollow spaces horizontal, plaster on both sides, each } \\
5 \text {, inch thick }\end{array}$ & 3. & 4.5 \\
\hline 5 & 12-inch tile wall, laid with hollow spaces vertical and directly over each other & 3. 09 & 2.10 \\
\hline$\frac{6}{7}$ & $\begin{array}{l}\text { Same as of test No. } 5 \text {, with } 1 \text { coat of dehydratine on high temperature side. } \\
\text { Same as of test No. } 5 \text {, plaster on both sides, each } 58 \text { inch thick }\end{array}$ & $\begin{array}{l}3.09 \\
3.75\end{array}$ & $\begin{array}{l}\text { 3. } 00 \\
3.39\end{array}$ \\
\hline
\end{tabular}

It appears that in some of the tests by Arkiey, infiltration of air through the wall was appreciable, and the application of a layer of paper, or a coat of dehydratine, which in themselves have but slight thermal resistance, increased the resistance of the wall. In those cases where infiltration of air was negligible, Arkley's results are in fair agreement with those of this paper.

${ }^{10}$ Results of Test Houses Erected by the Norwegian Technical Cniversity; published by F. Bruns Bokhandels Forlag, Trondhjem, 1924. 
Data by Willard and Lichty (University of Illinois, Bulletin No. 102, Vol. XV, No. 12; November 19, 1917)

\begin{tabular}{|c|c|c|}
\hline \multirow[b]{2}{*}{ Description } & \multicolumn{2}{|c|}{$R$} \\
\hline & $\begin{array}{l}\text { Calcu- } \\
\text { lated }\end{array}$ & $\mathrm{W}_{\mathrm{L} \text {. and }}$ \\
\hline $\begin{array}{l}\text { 8-inch brick wall } \\
\text { 2-inch hollow tile, } 1 / 2 \text {-inch plaster on each side... } \\
\text { 4-inch hollow tile, } 1 / 2 \text {-inch plaster on each side.-. } \\
6 \text {-inch hollow tile, } 1 / 2 \text {-inch plaster on each side..- }\end{array}$ & $\begin{array}{l}1.04 \\
.96 \\
1.47 \\
1.99\end{array}$ & $\begin{array}{l}2.00 \\
1.00 \\
1.67 \\
2.13\end{array}$ \\
\hline
\end{tabular}

Data by Kreuger and Erikson (Ingeniörs Vetenskaps Akademien, Handlingar $\mathrm{Nr}$. 36; published by A. B. Gunnar Tissels Tekniska Förlag, Stockholm, 1924)

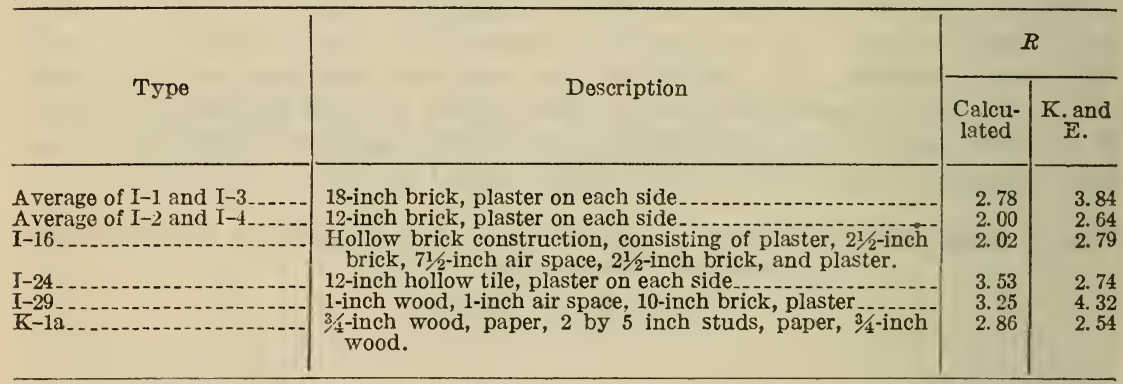

Data by Rowley, Morris, and Algren (Jour. A. S. H. V. E., 34, 1928; pp. 517-541)

[The following values not given in Table $\mathrm{V}$, are based on tests made at the Bureau of Standards]

1/2-inch gypsum board

0.38

$3 / 4$-inch sheathing

$3 / 8$-inch wood lath and $3 / 8$-inch plaster

Lap siding (same as clapboards)

\begin{tabular}{|c|c|c|c|}
\hline \multirow{2}{*}{$\begin{array}{l}\text { Wall } \\
\text { No. }\end{array}$} & \multirow{2}{*}{ Description } & \multicolumn{2}{|c|}{$R$} \\
\hline & & $\begin{array}{l}\text { Calcu- } \\
\text { lated }\end{array}$ & $\begin{array}{l}\text { R., M., } \\
\text { and A. }\end{array}$ \\
\hline \multirow{2}{*}{$\begin{array}{l}7 \\
7 \mathrm{a}\end{array}$} & 1/2-inch gypsum board, studding, 3/4-inch fir sheathing, paper and lap siding & 3.32 & 3. 51 \\
\hline & $\begin{array}{l}3 / 8 \text {-wood lath and 3/8-inch plaster, studding, 3/4-inch fir sheathing, paper and lap } \\
\text { siding }\end{array}$ & 3.57 & 3.57 \\
\hline 8 & 3/8-inch wood lath and $3 / 8$-inch plaster, studding, $3 / 1$-inch fir sheathing, paper and & \multirow{2}{*}{ 3. 57} & \multirow{2}{*}{ 3. 43} \\
\hline \multirow[t]{2}{*}{10} & 3/8-inch wood lath and 3/8-inch plaster, studding, insulating board B (Table 4 of & & \\
\hline & $\begin{array}{l}\text { R. M, and A.), paper and lap siding } \\
\text { 12-inch insulating board } B \text {, 3/8-inch plaster, studding, } 1 / 2-\text {-inch insulating board } \mathbf{B} \text {, }\end{array}$ & 4. 49 & \multirow{2}{*}{$\begin{array}{l}\text { 4. } 23 \\
5.61\end{array}$} \\
\hline 11 & paper and lap siding & 5. 70 & \\
\hline 20 & 36-inch lath and 3/8-inch plaster, studding, 3/4-inch fir sheathing, and lap siding & \multirow{2}{*}{ 3. 57} & \multirow{2}{*}{ 3. 58} \\
\hline 21 & 8-inch 3 -cell tile, 1 -inch furring strips, insulating board $\mathrm{B}$, $3 / 8$-inch plaster, stucco & & \\
\hline 22 & $\begin{array}{l}\text { on tile } \\
\text { 8-inch } 3-c e l l \\
\text { tile, plaster, stucco }\end{array}$ & $\begin{array}{l}5.06 \\
2.43\end{array}$ & 4. 52 \\
\hline 23 & $\begin{array}{l}1 / 2 \text {-inch insulating board } \mathrm{G} \text { ( Table } 4 \text { of } \mathrm{R} \text {. M. and } \mathrm{A} \text {.), studding, } 1 / 2 \text {-inch insulating } \\
\text { board } \mathrm{G} \text {. }\end{array}$ & 3. 84 & 3. 53 \\
\hline 24 & $\begin{array}{l}\text { 8-inch 3-cell tile, 1-inch furring strips, 38-inch lath and 38-inch plaster, stucco on } \\
\text { tile. }\end{array}$ & \multirow{2}{*}{$\begin{array}{l}3.85 \\
4.19\end{array}$} & \multirow{2}{*}{$\begin{array}{l}\text { 3. } 56 \\
\text { 4. } 09\end{array}$} \\
\hline $\begin{array}{l}25 \\
26\end{array}$ & $\begin{array}{l}1 / 2 \text {-inch insulation } \mathrm{B} \text {, studding, } 1 / 2 \text {-inch insulation } \mathrm{B} \\
1 / 2 \text {-inch insulation } \mathrm{G}, 3 / 8 \text {-inch plaster, studding, } 1 / 2 \text {-inch insulation } \mathrm{G} \text {, paper and }\end{array}$ & & \\
\hline 31 & lap siding & $\begin{array}{l}5.11 \\
6.78\end{array}$ & $\begin{array}{l}\text { 4. } 67 \\
\text { 5. } 78\end{array}$ \\
\hline
\end{tabular}


Data by E. Griffiths (Special Report No. 7, Building Research Board, Great Britain, Dept. of Sci. and Industrial Research; published in 1923)

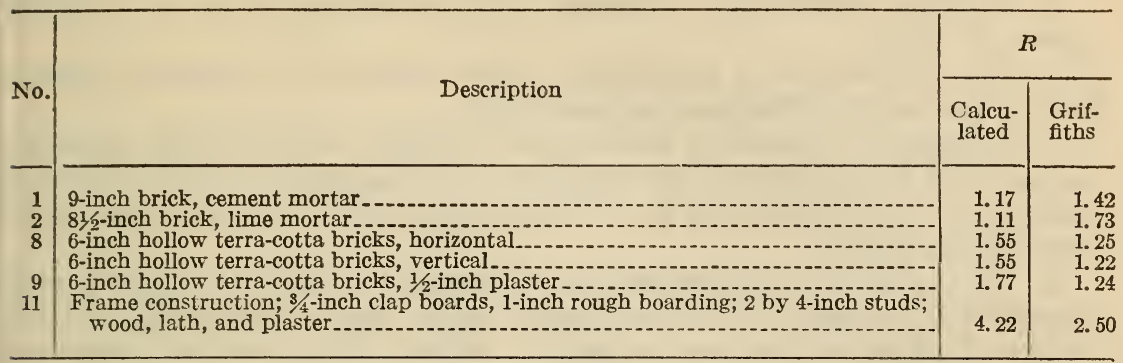

Some of the walls tested by Rowley, Morris, and Algren include insulation installed in a special manner, and it is useful to know the effect of these particular installations. The following values are based entirely on the data given by these experimenters. Under A is given a description of the insulation; under B, the method of application. In the column headed $\mathrm{C}$ is indicated the method of calculation, as for example resistance of wall No. 12 minus resistance of wall No. $7 \mathrm{a}$; and under the column headed D is given the increase in resistance due to the addition of the insulating material installed in the particular manner.

1 A. Quilted wood fiber between two layers of kraft

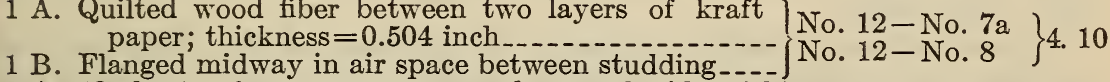

2 A. 40 sheets of newspaper, covered on each side with double waterproofed kraft paper.............

2 B. Flanged midway in air space between studding

3 A. Animal hair, lined on one side with tar paper, and on other side with heavy kraft paper; thickness $=0.269$ inch

$3 \mathrm{~B}$. Flanged midway in air space between studding

$4 \mathrm{~A}$. Quilted wood fiber between two layers of kraft paper; thickness $=0.550$ inch

4 B. Nailed on studding under sheathing

5 A. Porous gypsum material poured in place....... No. 17-No. $7 \mathrm{a}$

5 B. $3 \frac{1}{2}$ inches thick, poured between studding

6 A. Semirigid board; thickness $=0.567$ inch

7 A. Paper felt treated on the surfaces with creosote for waterproofing; thickness $=0.119$ inch__......- No. $28-$ No. $7 \mathrm{a}\} 2.26$

7 B. Two thicknesses of insulation spaced between studs No. $28-$ No. 8 , 2.26 to divide air space into three equal parts_._._. 8 B. One thickness of insulation nailed to each side of $\left.\begin{array}{l}\text { So. } 29-\text { No. } 7 \text { a } \\ \text { studs, bowed in at center } 1 \frac{1}{4} \text { inch } 29-\text { No. } 8\end{array}\right\} 1.79$ $\left.\begin{array}{l}\text { No. } 14-\text { No. } 7 \text { a } \\ \text { No. } 14-\text { No. } 8\end{array}\right\} 2.79$ $\left.\begin{array}{l}\text { No. } 15-\text { No. } 7 \mathrm{a} \\ \text { No. } 15-\text { No. } 8\end{array}\right\} 3.03$ No. 16-No. $7 \mathrm{a}\} 2.51$

\section{SUMMARY AND GENERAL CONCLUSIONS}

A method is described for measuring the thermal resistance of building wall sections under laboratory conditions. In this method all effects of air infiltration which may take place under actual weather conditions are eliminated. Results are given for a number of typical walls, and tables are included showing the thermal resistances of all ordinary wall components, so that the resistance of any combination of these components can be calculated.

The following general conclusions may be drawn from the results of the tests described. These conclusions are, of course, limited to the test conditions. 
1. In general, the presence of air spaces or pockets increases the insulating value of walls built of heavy clay products.

2. Furring materially increases the insulating value of ordinary types of walls.

3. The differences in insulating value between the various types of hollow tile walls tested are unimportant.

4. Judging by tests on two kinds of brick, representing approximately the two extremes in common brick manufacture, the kind of brick used in a brick wall is of little importance from the insulation standpoint alone.

5. The type of workmanship in a masonry wall may make a considerable difference in the insulating value, depending chiefly on the degree of filling of the mortar joints. Solidly filled vertical joints are not so effective from the insulation standpoint as partially filled joints.

6. The insulating value of all walls tested increases with decreasing temperature, the increase, in general, being more rapid with hollow walls than with solid walls.

It is pointed out that investigations carried out elsewhere indicate that air infiltration through finished walls plays a minor rôle in heat loss from buildings. The possibilities of heat loss by partial air penetration into hollow walls are discussed at some length, and it may be inferred that there is always a possibility that an individual wall of this type may be subject to air penetration effects of appreciable magnitude.

In conclusion, it might, perhaps, be emphasized that in an actual building, heat loss through windows, doors, and roof tend to level out the effect of differences in the walls themselves to a very considerable extent. It may, therefore, be said that although there are considerable differences in the insulating values of the various types of walls tested, the magnitude of these differences is not sufficient to make them a very important factor in the choice of building wall types, except, perhaps, in the case of relatively thin solid masonry without air spaces, where discomfort may be caused or moisture condensation produced by abnormally cold interior wall surfaces. As an illustration from another angle of the observed differences in uninsulated wall types, walls showing the lower insulating values could, by the addition of a half inch of good insulating material, be endowed with a thermal resistance approximately as great as those showing the higher insulating values in the tests described. The difference between the poorest and best wall from the viewpoint of thermal insulation (representing the extremes in ordinary uninsulated construction), is equivalent to approximately three-fourths inch of good insulating material.

\section{ACKNOWLEDGMENTS}

The authors wish to express their indebtedness to S. H. Ingberg, under whose supervision the frame, tile, and two of the brick walls were constructed. Most of the tests on brick construction were made possible by the assistance of the Common Brick Manufacturers' Association, represented by J. W. McBurney, under whose direction the brick panels were constructed. The cooperation of this association and of Mr. McBurney is gratefully acknowledged.

Washington, August 6, 1930. 